University of South Florida

DIGITAL COMMONS

Digital Commons @ University of

@ UNIVERSITY OF SOUTH FLORIDA

South Florida

Marine Science Faculty Publications

College of Marine Science

2015

\title{
Coastal Ocean Forecasting: Science Foundation and User Benefits
}

\author{
V. H. Kourafalou \\ University of Miami \\ P. De Mey \\ Laboratoire d'Etudes en Géophysique et Océanographie Spatiales \\ J. Staneva \\ Institute for Coastal Research \\ N. Ayoub \\ Laboratoire d'Etudes en Géophysique et Océanographie Spatiales
}

A. Barth

University of Liège

See next page for additional authors

Follow this and additional works at: https://digitalcommons.usf.edu/msc_facpub

\section{Scholar Commons Citation}

Kourafalou, V. H.; De Mey, P.; Staneva, J.; Ayoub, N.; Barth, A.; and Weisberg, Robert H., "Coastal Ocean Forecasting: Science Foundation and User Benefits" (2015). Marine Science Faculty Publications. 408. https://digitalcommons.usf.edu/msc_facpub/408

This Article is brought to you for free and open access by the College of Marine Science at Digital Commons @ University of South Florida. It has been accepted for inclusion in Marine Science Faculty Publications by an authorized administrator of Digital Commons @ University of South Florida. For more information, please contact digitalcommons@usf.edu. 


\section{Authors}

V. H. Kourafalou, P. De Mey, J. Staneva, N. Ayoub, A. Barth, and Robert H. Weisberg 


\title{
Coastal Ocean Forecasting: science foundation and user benefits
}

\author{
V.H. Kourafalou, P. De Mey, J. Staneva, N. Ayoub, A. Barth, Y. Chao, M. Cirano, \\ J. Fiechter, M. Herzfeld, A. Kurapov, A.M. Moore, P. Oddo, J. Pullen, A. van der \\ Westhuysen \& R.H. Weisberg
}

To cite this article: V.H. Kourafalou, P. De Mey, J. Staneva, N. Ayoub, A. Barth, Y. Chao, M. Cirano, J. Fiechter, M. Herzfeld, A. Kurapov, A.M. Moore, P. Oddo, J. Pullen, A. van der Westhuysen \& R.H. Weisberg (2015) Coastal Ocean Forecasting: science foundation and user benefits, Journal of Operational Oceanography, 8:sup1, s147-s167, DOI: 10.1080/1755876X.2015.1022348

To link to this article: https://doi.org/10.1080/1755876X.2015.1022348

\section{(c) 2015 The Author(s). Published by Taylor \& Francis.}

冓 Published online: 09 Jun 2015.

6 Submit your article to this journal ए]

Џll Article views: 1728

View Crossmark data ¿

Citing articles: 13 View citing articles $[7$ 


\title{
Coastal Ocean Forecasting: science foundation and user benefits
}

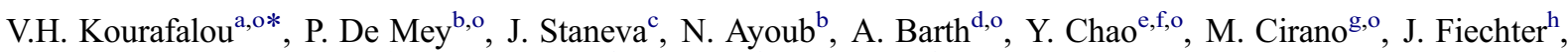 \\ M. Herzfeld ${ }^{\mathrm{i}, \mathrm{o}}$, A. Kurapov ${ }^{\mathrm{j}, \mathrm{o}}$, A.M. Moore ${ }^{\mathrm{h}}$, P. Oddo ${ }^{\mathrm{k}, \mathrm{o}}$, J. Pullen ${ }^{1, \mathrm{o}}$, A. van der Westhuysen ${ }^{\mathrm{m}, \mathrm{o}}$ and R.H. Weisberg $^{\mathrm{n}}$ \\ ${ }^{a}$ University of Miami, Rosenstiel School of Marine and Atmospheric Sciences, Miami, FL, USA; ${ }^{b}$ Laboratoire d'Etudes en Géophysique et \\ Océanographie Spatiales, Toulouse, France; ${ }^{c}$ Institute for Coastal Research, Helmholtz-Zentrum, Geesthacht, Germany; ${ }^{d}$ GHER, MARE, \\ AGO, University of Liège, Belgium; ${ }^{e}$ Remote Sensing Solutions, Pasadena, California, USA; ${ }^{f}$ University of California, Joint Institute for \\ Regional Earth System Science and Engineering, Los Angeles, CA, USA; ${ }^{g}$ Federal University of Bahia, Tropical Oceanography Group, \\ Institute of Physics, Brazil; ${ }^{h}$ University of California Santa Cruz, Department of Ocean Sciences, CA, USA; ${ }^{i}$ CSIRO, Hobart, Australia; \\ ${ }^{j}$ Oregon State University, College of Earth, Oceanic, and Atmospheric Sciences, Corvallis, OR, USA; ${ }^{k}$ Istituto Nazionale di Geofisica e \\ Vulcanologia, INGV, Bologna, Italy; 'Stevens Institute of Technology, Hoboken, NJ, USA; ${ }^{m}$ NOAA/NCEP/EMC/Marine Modelling and \\ Analysis Branch, College Park, MD, USA; ${ }^{n}$ University of South Florida, College of Marine Science, St. Petersburg, FL, USA; ${ }^{\circ}$ Coastal and \\ Shelf Seas Task Team Member, GODAE OceanView
}

\begin{abstract}
The advancement of Coastal Ocean Forecasting Systems (COFS) requires the support of continuous scientific progress addressing: (a) the primary mechanisms driving coastal circulation; (b) methods to achieve fully integrated coastal systems (observations and models), that are dynamically embedded in larger scale systems; and (c) methods to adequately represent air-sea and biophysical interactions. Issues of downscaling, data assimilation, atmosphere-wave-ocean couplings and ecosystem dynamics in the coastal ocean are discussed. These science topics are fundamental for successful COFS, which are connected to evolving downstream applications, dictated by the socioeconomic needs of rapidly increasing coastal populations.
\end{abstract}

\section{Introduction}

The development and evolution of Coastal Ocean Forecasting Systems (COFS) are largely dependent on both technological and scientific advances, as well as on user needs. Continuous monitoring, in tandem with numerical modelling techniques, over a range of spatial and temporal scales are fundamental components for the success of COFS. Integrated coastal observing and modelling systems have been emerging, progressively combined with regional and global systems, substantially advancing the quality of coastal forecasts and the services they can provide in support of societal and economic needs. Such activities are supported by international coordination under the Coastal Ocean and Shelf Seas Task Team (COSS-TT) within GODAE OceanView http://godaeoceanview.org. Examples of integrated systems and supporting approaches are given in a companion paper (Kourafalou et al. 2015). Here, the focus is on specific science issues and applications that drive the scientific developments which in turn enable COFS.

An adequate COFS should be able to monitor, predict and disseminate information about the coastal ocean state and thus cover a wide range of coastal processes. These include: mesoscale and sub-mesoscale shelf break exchanges, shelf dynamics, fronts, connectivity, slope currents, storm surges, tides, internal waves, surface waves, swell, upwelling, transport of nutrients, sediments and pollutants, estuarine processes, river plumes, and topographic controls on circulation. The land-sea interaction is governed by coastal runoff and the resulting buoyancy-driven circulation and material transport. Air-sea interaction generally occurs at short time and small space scales, driven by local orographic features and/or temperature differences between land and sea, which modulate and modify the large scale atmospheric flow.

Several components are needed to achieve these goals: a multidisciplinary, multiscale observational network; a state of the art modelling suite integrating the primitive equations and solving explicitly for the particular physical processes characterizing the coastal area; a robust data assimilation scheme accounting for anisotropy and complex cross correlations between errors in environmental variables; and a suite of dissemination tools able to scientifically integrate the information collected and transform it into products serving the community (scientists, policy makers, maritime stakeholders).

Coastal ocean disciplines are still advancing along active research topics. This evolution requires the

\footnotetext{
*Corresponding author. Email: vkourafalou@rsmas.miami.edu 
development of adequate observational networks to monitor and further understand the coastal ocean. Advanced understanding should provide new processes to be implemented and/or parameterized in ocean models to cover the observational gaps, but also to study the whole coastal ocean system and interactions that are impossible to solve analytically. Numerical models have limitations due to intrinsic errors, thus data assimilation schemes must be developed in parallel, accounting for the new processes and scales required to correct and drive the numerical results. Finally, methods integrating the very complex resulting information obtained in simple and usable ways must be developed.

The goal of this paper is to discuss areas where scientific progress is crucial for the development of COFS and the expected benefits that COFS can provide to the society at large and to specific users. The next section focuses on four major scientific aspects that are currently active areas of research: downscaling, coastal data assimilation and two types of inter-disciplinary couplings (circulationwaves, physics-biogeochemistry). This is followed by a discussion on a broad range of applications that are closely linked to the key science areas, while targeting user needs, with a focus on societal benefits. Concluding remarks focus on advances and benefits.

\section{Science in support of coastal forecasting \\ Downscaling the ocean estimation problem}

The coastal ocean circulation is driven by a combination of local (winds, atmospheric fluxes, land drainage and tides) and deep-ocean forcings (along the shelf slope). Both of these influences must be included in COFS. Downscaling is accepted as the preferred methodology to propagate the large scale dynamics into COFS, through boundary conditions from Global Ocean Forecasting Systems (GOFS) (Auclair et al. 2001; Dombrowsky et al. 2009). The boundary conditions must capture relevant far-field phenomena, such as swells from distant storms in wave models, or thermodynamic gradients and tidal information in circulation models. The forcing data and the representation of the coastal model geometry must be also appropriately scaled, with details that are often missing from the outer model.

Needs in boundary conditions, topography and forcing functions

An important downscaling issue arises from the fact that the large-scale solution is unbalanced with respect to the local physics of the embedded model, due to the different resolutions, bathymetries, numerical boundary conditions, etc. Simple interpolation may lead to problems, such as triggering unrealistic gravity transients. An assessment of the sensitivity of the prescribed values imposed is generally recommended since the parent models may have different configurations, regarding their physics or even the space and time resolution of the outputs used (Kourafalou et al. 2009; Marta-Almeida et al. 2013a, Guillou et al. 2013). The added value of nesting in GOFS, versus using climatological or open boundary conditions is noted (De Mey et al. 2009; Zamudio et al. 2011).

A multi-nested downscaling approach is often employed, which involves the construction of one or more models of increasing spatial resolution, each nested inside the other and receiving information representing the larger scale dynamics from the coarser model via open boundary conditions (OBCs). This can be accomplished in a one-way sense where information is only propagated toward higher resolution, or a twoway interaction where the fine scale (or 'child') model delivers information back to the larger scale (or 'parent') model (Mason et al. 2010; Debreu et al. 2012). The OBCs are crucial in such a transfer of information. However, the OBC problem is ill-posed, and no perfect boundary condition exists (Oliger \& Sundstrom 1978). Fortunately, a large amount of literature exists on the subject, so the issues are clearly articulated (Marsaleix et al. 2008; Herzfeld et al. 2011).

Since OBCs are not perfect, the information that they deliver to the model interior often contains error. If the boundary tries to impose information that is strongly in conflict with what the model is attempting to do in the interior, then over-specification error results which often leads to instability or spurious boundary re-circulations. If insufficient information is delivered at the boundary, then under-specification error results and interior solutions can diverge from observations. Typically, attempts to minimize errors are made by radiating signals approaching the boundary from the interior out of the domain (Blumberg $\&$ Kantha 1985; Flather 1988). The typical use of a nogradient condition for baroclinic velocity gives a nonconservative or inconsistent boundary cell. The use of a correctly implemented Dirichlet condition can lead to an unconstrained sea level (i.e. no OBC required), which can respond perfectly to incoming and outgoing perturbations and is conservative (Herzfeld \& Andrewartha, 2012).

Implementation of the $\mathrm{OBC}$ equation (i.e. relative position of the normal velocity boundary face relative to the boundary cell center) is important, as it has been shown that the same boundary equation yields different solutions when implemented differently (Herzfeld 2009). These OBCs are often supplemented with sponge zones where friction is increased, flow relaxation schemes to combine external data and model solutions or nudging zones to relax solutions to external data, primarily to improve stability (Treguier et al. 2001; Martinsen and Engedahl 1987; Marchesiello et al. 2001). Applications using two way 
nesting are gaining popularity (Jouanno et al. 2008; Cailleau et al. 2008; Debreu \& Blayo 2008). These approaches still have issues regarding conservation, which can be achieved at the expense of variable continuity, or can be a source of instability, particularly for non-aligned bathymetries and meshes (Cailleau et al. 2008; Debreu et al. 2012). However, the advantage of the approach is that individual nests are associated with their own time-step, which can improve computational efficiency.

Obtaining sufficiently detailed and representative bathymetric data needed for COFS models is both critical and a challenge. Whereas in oceanic applications bathymetric sources such as ETOPO1 (1 arc-min horizontal resolution, vertical accuracy within $10 \mathrm{~m}$ ) may be sufficient, higher-resolution data are required for the coast. In the U.S, the most reliable bathymetric data source is from the National Oceanic and Atmospheric Administration (NOAA) VDatum project, combining bathymetric (sounding) and topographic (LIDAR) data. Another challenge is that coastal topography and bathymetry change on both intraand inter-storm scales (e.g. bar formation during severe winter storms). It is, therefore, challenging to establish representative bathymetry in coastal models. Although it is possible to include morphological processes such as erosion and breaching, it is operationally unfeasible at present. Modelling at coastal scales also increases demands on atmospheric forcings: higher spatial resolutions and accurate land models (e.g. North American Mesoscale system, NAM, from NOAA's National Centers for Environmental Prediction, NCEP) are required to capture coastal features. Marine meteorological processes, such as landsea breezes, and river inflows become important in the coastal oceanic models, and must be captured adequately.

\section{Examples of downscaling to resolve reefs and estuaries}

The Greater Barrier Reef (GBR) in Australia is a unique system, associated with its own set of specific dynamics that require a downscaling approach. Scales from the open ocean to the reef (from kilometers to meters) are seamlessly addressed through the eREEFS system (Schiller et al. 2014; Kourafalou et al. 2015). Within the GBR, the low frequency sea level response is primarily generated by wind stress within the lagoon (Burrage et al. 1991; Brinkman et al. 2002). From a downscaling perspective, using open boundaries, this implies the use of a passive open boundary. However, the tides are large and warrant the use of an active boundary. $\mathrm{OBCs}$ with no or single relaxation timescales struggle to reconcile these requirements; hence, a dual relaxation method $\mathrm{OBC}$ is implemented to sequentially represent the dynamics at these two different time-scales (Herzfeld \& Andrewartha 2012).

The Florida Keys in the US are characterized by unique interactions between a long reef system and a boundary current. A rich eddy field associated with the meandering
Gulf Stream has a direct influence on reef flows and the replenishment of coral reef fishes, which are resolved through a downscaling approach from the global to the regional (Gulf of Mexico) and the reef scale (Kourafalou and Kang 2012; Sponaugle et al. 2005).

Forecasting estuarine circulation is in high demand, especially in regions of high population density like the San Francisco Bay/Estuary, largest estuary on the US Pacific coast and the largest wetland habitat in the western US. This system is modeled by the Semi-implicit Eulerian-Lagrangian Finite-Element (SELFE) modelling system (Figure 1). SELFE is an unstructured-grid model designed for the effective simulation of 3D baroclinic circulation across river-to-ocean scales (Zhang \& Baptista, 2008). Horizontal resolution at the coastal boundary is $1 \mathrm{~km}$, increasing to $10 \mathrm{~m}$ in the estuary. A regional mesoscale atmospheric model (the US Navy's Coupled Ocean-Atmosphere Mesoscale Prediction System, COAMPS) provides atmospheric forcing. Boundary conditions outside the Golden Gate bridge are derived from a California coastal model $(3 \mathrm{~km}$ horizontal resolution and 40 vertical layers) based on the Regional Ocean Modelling System ROMS, http://myroms.org, extensively validated using field observations (Hodur et al. 2002; Doyle et al. 2009; Shchepetkin \& McWilliams 2005; Chao et al. 2008; Chao et al. 2009; Ramp et al. 2009; Wang et al. 2009).

The influence of the coastal ocean on the bay/estuary circulation and variability is clearly shown in Figure 1. The tides entering through the Golden Gate can raise the San Francisco Bay water level as high as $2 \mathrm{~m}$ (not shown). Figure 1 shows model to data agreement that tidal induced salinity variations can be as large as 3. In addition to tidal fluctuations, the Bay/Estuary system also exhibits significant variability on time scales from days to years, presumably forced by a combination of river discharge, atmospheric forcing and coastal ocean circulation.

For the eastern Gulf of Mexico, the utility of downscaling from the deep ocean, across the continental shelf and into the estuaries has been demonstrated (Zheng \& Weisberg 2012). The unstructured, Finite Volume Coastal Ocean Model (FVCOM), e.g. Chen et al. (2003), was first nested in the Global Hybrid Coordinate Ocean Model HYCOM, http://hycom.org, e.g. Chassignet et al. (2009), and eight tidal constituents were added along the open boundary. Along with hindcast simulations that were quantitatively assessed against available in-situ observations, the model evolved to producing daily, automated nowcasts/forecasts (WFCOM, West Florida Coastal Ocean Model, subsequently nested into the regional $1 / 25^{\circ}$ Gulf of Mexico HYCOM, Figure 2). Horizontal resolution varies from that of HYCOM along the open boundary to $150 \mathrm{~m}$ in the estuaries. Local forcing includes surface winds and heat fluxes from NOAA/NCEP NAM reanalyses 

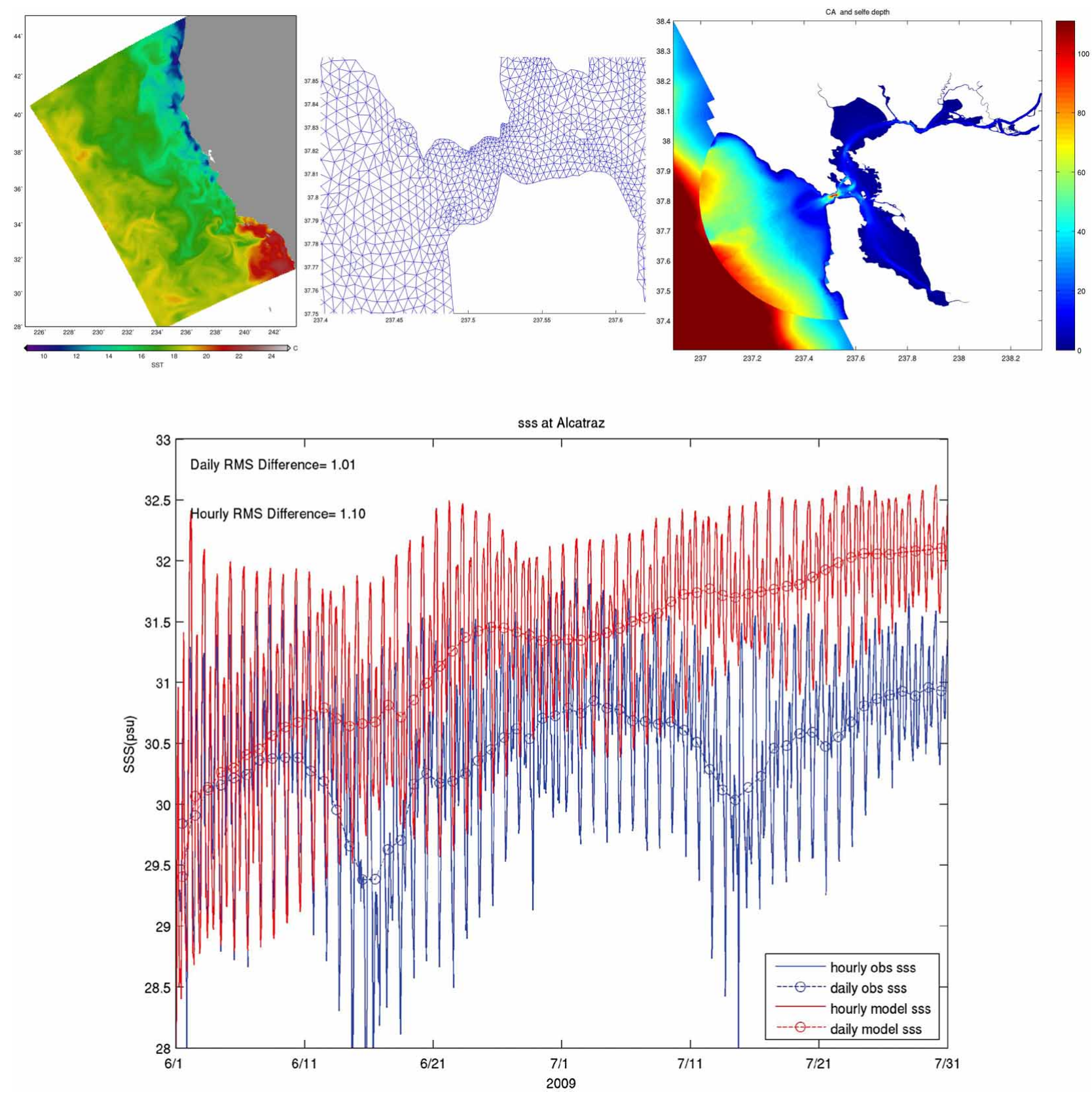

Figure 1. (Top): Schematic diagram showing the one-way coupling between a structured grid ROMS off the California coast (left) and an unstructured grid SELFE over the San Francisco Bay/Estuary and lower Sacramento River (right). The left panel shows ROMS simulated SST. The middle panel shows the triangle unstructured grids on both sides of the Golden Gate bridge (narrowest passage on grid). The right panel shows the bottom topography (in meters) used by both ROMS and SELFE, with the thick black line representing the coupling boundary between ROMS and SELFE. (Bottom): Time series of water surface salinity as measured near Golden Gate (blue lines) and simulated by SELFE (red lines) during June-July 2009. Solid lines: hourly; dashed-circles: daily averages.

and river inflows. This model is an important step toward future downscaling to resolve inlets and shipping channels, as for the adjacent Tampa Bay system (Zhu et al. 2014a,b). Such further downscaling may be useful when deep-ocean influences could drive contaminants from distant regions to an estuary or when species may migrate between different estuarine or shelf habitats. Under such scenarios the ability to resolve the principal inlets that serve as mass conveyances and include sediment dynamics may be important.

\section{Coastal data assimilation and prediction}

Data assimilation (DA) frameworks have been used in coastal ocean models to control the model trajectory and minimize errors, toward enhancing the model's predictive 

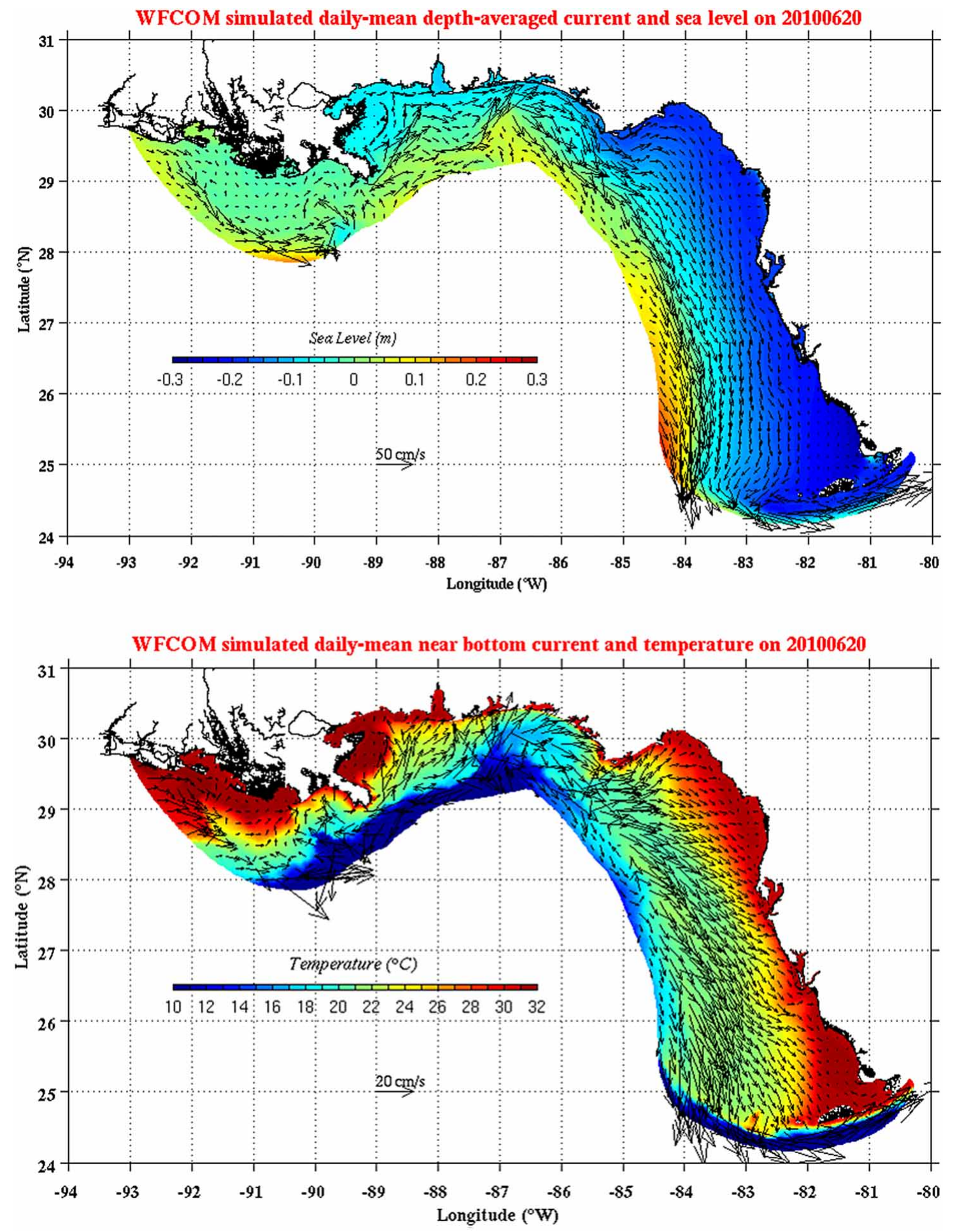

Figure 2. Snapshots on 20 June 2010 from a year-long WFCOM hindcast simulation. (Top): Daily and vertically averaged current velocity superimposed on sea surface height. (Bottom): daily averaged near-bottom velocity and temperature. The coherent southward oriented circulation seen on the west Florida continental shelf is a consequence of a prolonged Gulf of Mexico Loop Current interaction with the shelf slope near the southwest corner of the model domain. The relative high sea level perturbation seen near the southwest corner $(\sim 25 \mathrm{~N}$, $84 \mathrm{~W})$ propagated to the north and west setting up a geostrophic current on the shelf itself, and left-hand turning in the bottom Ekman layer resulted in a pronounced upwelling that extended across the entire shelf, resulting in cold bottom water right up to the shoreline. 
capabilities. These topics are discussed below. Such frameworks have also been used for array design (including Observing System Experiments/Observing System Simulation Experiments; OSE/OSSEs) and probabilistic forecasting (Kourafalou et al. 2015).

\section{Accounting for model uncertainties}

Many factors contribute to errors in coastal ocean model forecasts. These may include: imperfect atmospheric forcing fields; errors in boundary conditions propagating inside the finer scale model domain; bathymetric errors (more consequential in coastal regions); insufficient horizontal and vertical resolution and numerical noise and bias; errors in parameterizations of atmosphere-ocean interactions and sub-grid turbulence; intrinsic limited model predictability (strong non-linearity), etc. To improve the quality of prediction, the model estimates are combined with available data by means of DA. Many different flavors of DA have been developed, tested, and implemented in numerical weather prediction and ocean forecasting. Some methods, including Optimal Interpolation (OI), 3-dimensional variational (3DVAR), and Ensemble Kalman Filter (EnKF), provide instantaneous corrections to the present ocean estimate sequentially, at relatively short time intervals (several hours in the context of a shelf scale model) (Oke et al. 2002; Li et al. 2008a; Evensen 2003). The 4-dimensional variational (4DVAR) DA method finds corrections to model inputs (possibly including initial conditions, atmospheric forcing, boundary conditions, and errors in the dynamical equations) by minimizing the model-data misfit over a relatively large interval between the recent past and the present time (3-10 days in context of shelf and regional scale models) (Bennett 2002; Moore et al. 2011a; Kurapov et al. 2011). In addition to the nonlinear forecast model, 4DVAR utilizes the corresponding tangent linear and the adjoint codes (Talagrand \& Courtier 1987; Moore, 1991; Errico \& Vukićević 1992). The main advantage is that the observational error is filtered not only by interpolation in space, but also in time.

Since observations are often sparser in coastal regions that in the open ocean, in particular considering the short space/time scales of error processes, error covariances for the model estimates are critical since they provide interpolation between the sparse observations, smoothing of the DA correction, and dynamical constraints on the correction fields (Kourafalou et al. 2015). In the coastal ocean, these covariances may be strongly inhomogeneous due to the coastal dynamics. For instance, large river plumes are associated with strong vertical and horizontal variability in stratification and water properties. To account for this spatial and temporal variability, the model error covariance may be computed using an ensemble of simulations. An example is given in Figure 3, around the Columbia River (US West coast).
In order to guide the implementation of the DA scheme, background errors and model uncertainties must be characterized, both physically and statistically. This is demonstrated through an example from the Bay of Biscay (Northeast Atlantic), where an Ensemble-based DA method is being implemented to improve the realism of regional simulations, by constraining the model with Sea Surface Temperature (SST) and Sea Surface Height (SSH) observations.

The SYMPHONIE ocean model is designed to represent the coastal circulation, including tides (Marsaleix et al. 2008). The model is configured with a $3 \mathrm{~km}$ by 3 $\mathrm{km}$ horizontal resolution, 43 terrain-following (sigma) levels, and nesting in the operational MERCATOR-Océan North-Atlantic model. The main processes of interest are the slope current variability along the Spanish and French slopes (located between the $200 \mathrm{~m}$ and $2000 \mathrm{~m}$ isobaths of Figure 4), the mesoscale activity induced by instabilities of the slope current and developing in the abyssal plain, and the surface circulation response to wind forcing at synoptic scales (a few days). As a first step towards DA, perturbation-driven Ensemble (free) runs of the model were performed, in order to characterize and quantify the model error at daily/monthly to seasonal time scales. Wind forcing perturbations were employed to generate the ensemble (Auclair et al. 2003).

The results of a 54-member ensemble over a 6-week period are discussed. This ensemble was started 1.5 month earlier from an initial state given by the MERCATOR-Océan North-Atlantic model. The model error was estimated as the ensemble spread (standard deviation about the ensemble mean). Figure 4 shows the ensemble spread in SSH (left) and SST (right) for a particular date (25 March 2008). The analysis over the whole study period provides evidence of two regimes of the model errors: over the shelf and over the deep ocean. The spread was found to be larger over the shelf $(>5 \mathrm{~cm}$ and $>0.5^{\circ} \mathrm{C}$ ) and shows a much larger time variability. The $\mathrm{SSH}$ spread reaches values up to $10 \mathrm{~cm}$ over the Celtic shelf and in the English Channel, probably because of wind effects at daily time scales. In the Bay of Biscay (south of $49 \mathrm{~N}$ ) the maximum spread for SSH is right at the coast and likely also corresponds to wind-driven surges. The SST maximum is farther offshore between the $100 \mathrm{~m}$ and $200 \mathrm{~m}$ isobaths. Over the abyssal plain, the spread in SST is relatively weak $\left(<0.3^{\circ} \mathrm{C}\right)$, grows little with time and is characterized by small-scale filament-like patterns. In contrast, the spread in SSH in the deep part is almost zero until 15 February, growing continuously up to about $6 \mathrm{~cm}$ at the end of the simulation, with spatial scales of a few hundreds of $\mathrm{km}$. In analogy to results found in the Gulf Stream area with a similar method, the growth in spread in SSH over the abyssal plain is interpreted as the signature of the mesoscale decorrelation, namely the increasing differences with time on the 


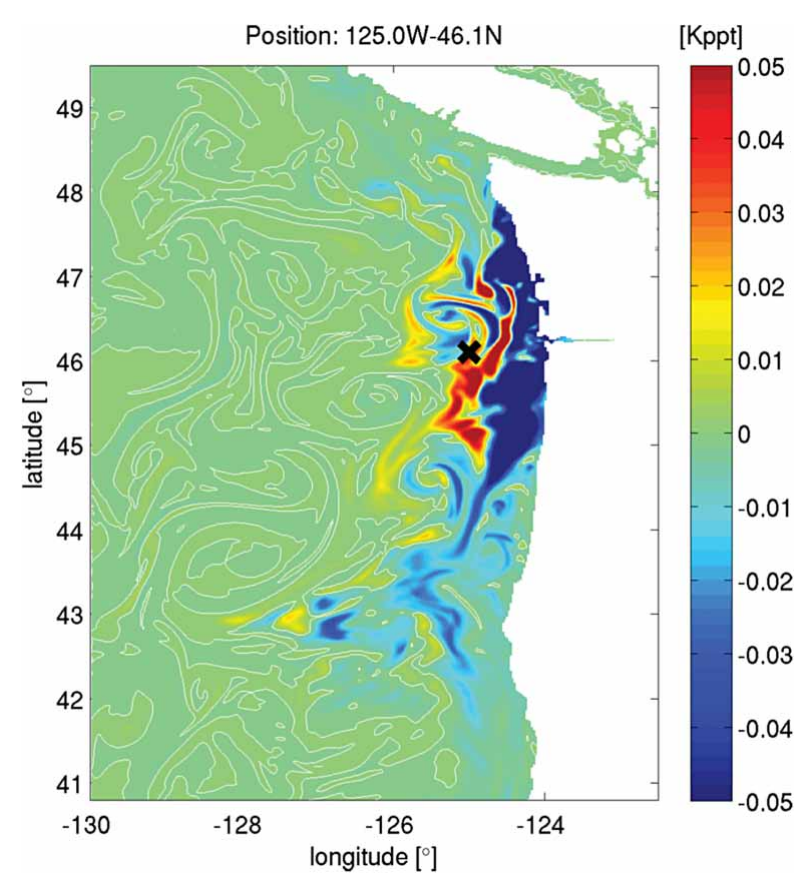

Figure 3. Model error covariance computed using an ensemble of ROMS-based estimates along the US West Coast shows a complicated pattern of co-variability between sea surface temperature at a point (marked by black ' $\mathrm{x}$ ', $125 \mathrm{~W}, 46.2 \mathrm{~N}$ ) and sea surface salinity everywhere, influenced by the presence of the Columbia River plume (discharging at $46.2 \mathrm{~N}$ ). Note abrupt change from positive (red) to negative (blue) covariance across the river front.

representation of eddies between members (Lucas et al. 2008).

The above example emphasizes the existence of two very distinct regimes over the shelf and in the deep ocean. DA methods should account for such distinct error behaviors and be designed accordingly. In particular, the choice of stationary or flow-independent model error covariances would not be adequate in such regions.

\section{Error covariance localization for coastal models}

A new methodology in adaptive covariance localization is presented. Ensemble DA schemes generally require the use of covariance localization to avoid spurious long-range correlations. These correlations arise from the limited number of ensemble members that one can afford to run with a realistic ocean model and should thus average out if the number of ensemble members could be increased. Covariance localization is generally simply based on the horizontal distance between an individual observation point and a given model grid point (Hamill et al. 2001; Houtekamer \& Mitchell 2001). This distance is scaled by a length-scale which can be interpreted as the maximum allowed correlation length. However, this is an ad hoc approach that can also filter out realistic long-range correlations (introduced for example through errors in the atmospheric fields) and such localization does not remove spurious correlation between weakly related model variables. Anisotropic covariances found in the coastal region makes such localization a difficult task for coastal ocean models (Barth et al. 2007; Li et al. 2008b; Tandeo et al. 2014).

A method similar to bootstrapping in statistics can be used to determine which analysis increments are statistically robust. The ensemble is randomly split in two subensembles and the analysis is carried out separately in each. The analysis increments of those sub-ensembles are compared and the procedure is repeated several times with different sub-ensembles. The resulting variance of the analysis increment is used to identify where the analysis is statistically robust. The method effectively uses an ensemble of Kalman gain matrices reflecting (to some extent) their uncertainty. In the context of the EnKF, one can update every ensemble member with a different Kalman gain matrix to take this uncertainty into account. This approach has thus also the potential to reduce the need of covariance inflation.

An example of the covariance localization is presented with ensemble simulations of the Ligurian Sea using ROMS nested in the Mediterranean Ocean Forecasting System (Dobricic et al. 2007). The model has $1 / 60^{\circ}$ resolution and 32 vertical levels. Atmospheric forcings come from the limited-area model COSMO (hourly at $2.8 \mathrm{~km}$ resolution). An ensemble simulation (with 100 members) was carried out, where zonal and meridional wind forcing, boundary conditions (elevation, velocity, temperature and salinity) were perturbed. The model was further perturbed by adding a stochastic term (without divergence) to the momentum equation. 

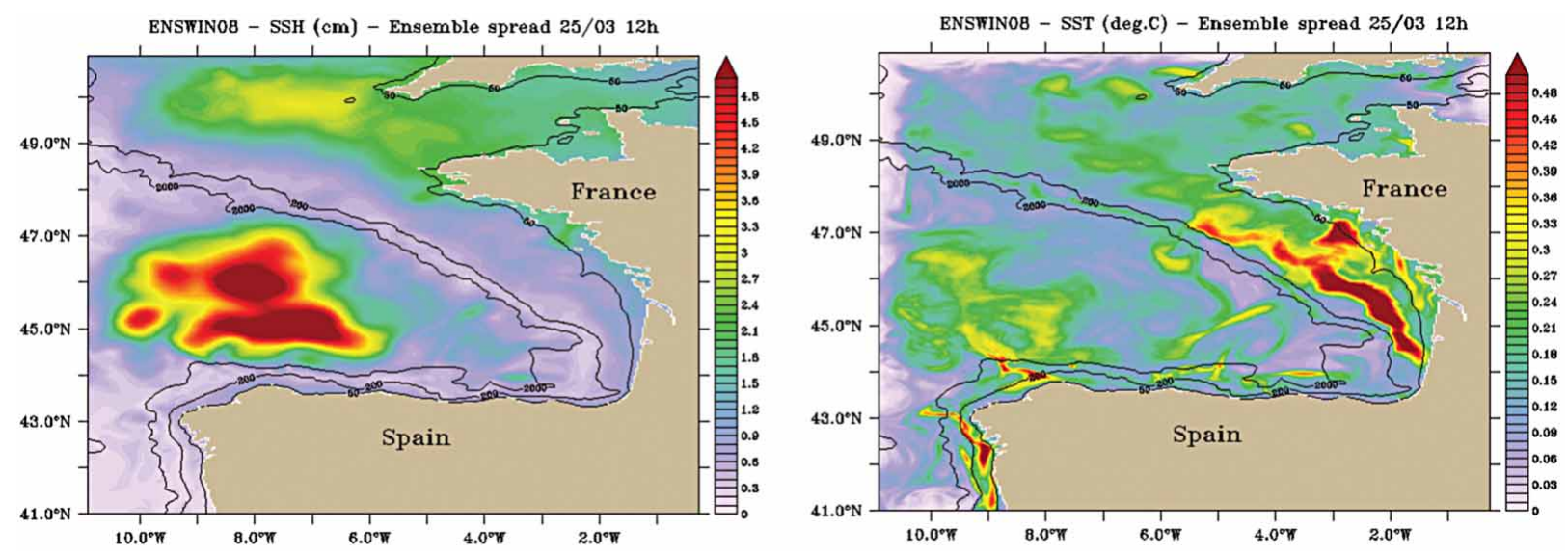

Figure 4. Ensemble spread on 25 March 2008, of sea surface height in $\mathrm{cm}$ (left) and sea surface temperature in ${ }^{\circ} \mathrm{C}$ (right) based on the SYMPHONIE model; the ensemble is generated by perturbing the wind forcing.

The effect of the localization using the bootstrap method is shown in Figure 5, where a scalar observation of the u-velocity (at the location of the marker) with a hypothetical value of $0.1 \mathrm{~m} / \mathrm{s}$ is assimilated with an observational error covariance of $0.1 \mathrm{~m}^{2} / \mathrm{s}^{2}$. The observation is located in a highly variable area. The global analysis produces significant spurious long-range correlation, especially with parts of the domain having a large error variance. The standard deviation of the increment determined by bootstrapping is large in areas such as the Gulf of Genoa (44.2N, 9.4E), North West of Cap Car's (43.2N, 9.7E) and south of Elba $(42.6 \mathrm{~N}, 10.5 \mathrm{E})$, where the global scheme resulted in a large correction. This indicates that the correction in these areas is not statistically robust. The localization envelope based on the increment standard deviation filters out these large range correlations and only selects corrections close to the location of the observation. The resulting length-scale is not determined a priori, but by the result of the bootstrapping analysis.

\section{Toward real-time data assimilation systems}

DA has been applied to multiple state estimation efforts for the California Current System (CCS, US West Coast, WC) with ROMS (4DVAR) (Moore et al. 2011a; Moore et al. 2011b). These include a near real-time (NRT) quasi-operational nowcast/forecast system (WCNRT) and the computation of two sequences of historical reanalyses for the CCS (West Coast ReAnalysis, WCRA). Both near real-time and historical systems are based on the nonlinear model configuration of Veneziani et al. (2009). The model domain (Figure 6a) extends from $30 \mathrm{~N}$ to $48 \mathrm{~N}$ and offshore to $134 \mathrm{~W}$, encompassing a substantial portion of the CCS. Horizontal resolution of $1 / 10^{\circ}$ resolves regional mesoscale variability, and 42 terrain-following levels span the water column. One sequence of reanalyses spans the 31-year period 1980-2010 (hereafter WCRA31), while the second sequence spans the 14-year period 1999-2012 (hereafter WCRA14). The two historical analyses differ in the prior surface forcing that is used to drive the model.

Table 1. A summary of the observation types, observing platforms, data sources, the nominal measurement errors, and the period covered for the US West Coast (WC) data assimilative simulations (WC Reanalyses, WCRA). They comprise satellite SST from multiple platforms, satellite-derived SSH, and in-situ hydrographic observations from all available platforms (including Argo profiling floats) in the EN3 quality controlled data base of Ingleby and Huddleston (2007) that fall within this domain.

\begin{tabular}{|c|c|c|c|c|c|c|c|}
\hline Observation type & $\begin{array}{l}\text { Observing } \\
\text { platform }\end{array}$ & Source & $\begin{array}{c}\text { Nominal } \\
\text { observation error }\end{array}$ & $\begin{array}{l}\text { Period } \\
\text { covered }\end{array}$ & $\begin{array}{c}\text { Near real } \\
\text { time system }\end{array}$ & WCRA31 & WCRA14 \\
\hline SSH & Altimeter & AVISO, 1 day average & $0.04 \mathrm{~m}$ & 1993-present & $\mathrm{x}$ & $\mathrm{x}$ & $\mathrm{x}$ \\
\hline $\mathrm{SSH}$ & Tide gauge & $\begin{array}{l}\text { NOAA, tidal } \\
\text { average }\end{array}$ & $0.02 \mathrm{~m}$ & 2011-present & $\mathrm{x}$ & & \\
\hline SST & $\begin{array}{l}\text { AVHRR/ } \\
\text { Pathfinder }\end{array}$ & $\begin{array}{l}\text { NOAA Coast } \\
\text { Watch }\end{array}$ & $0.6^{\circ} \mathrm{C}$ & 1981-present & & $\mathrm{x}$ & $\mathrm{x}$ \\
\hline SST & AMSR-E & $\begin{array}{l}\text { NOAA Coast } \\
\text { Watch }\end{array}$ & $0.7^{\circ} \mathrm{C}$ & $2002-2010$ & & $\mathrm{x}$ & $\mathrm{x}$ \\
\hline SST & MODIS-Terra & NASA JPL & $0.3^{\circ} \mathrm{C}$ & 2000-present & & $\mathrm{x}$ & $\mathrm{x}$ \\
\hline SST & Various & OSTIA & $0.4^{\circ} \mathrm{C}$ & 2011-present & $\mathrm{x}$ & & \\
\hline Hydrographic data & Various & UK Met. Office & $\mathrm{T}: 0.5^{\circ} \mathrm{C} \mathrm{S}: 0.1$ & 1950-present & & $x$ & $\mathrm{x}$ \\
\hline Hydrographic data & Glider & CeNCOOS & $\mathrm{T}: 0.1^{\circ} \mathrm{C} \mathrm{S:} 0.01$ & 2011-present & $\mathrm{x}$ & & \\
\hline
\end{tabular}



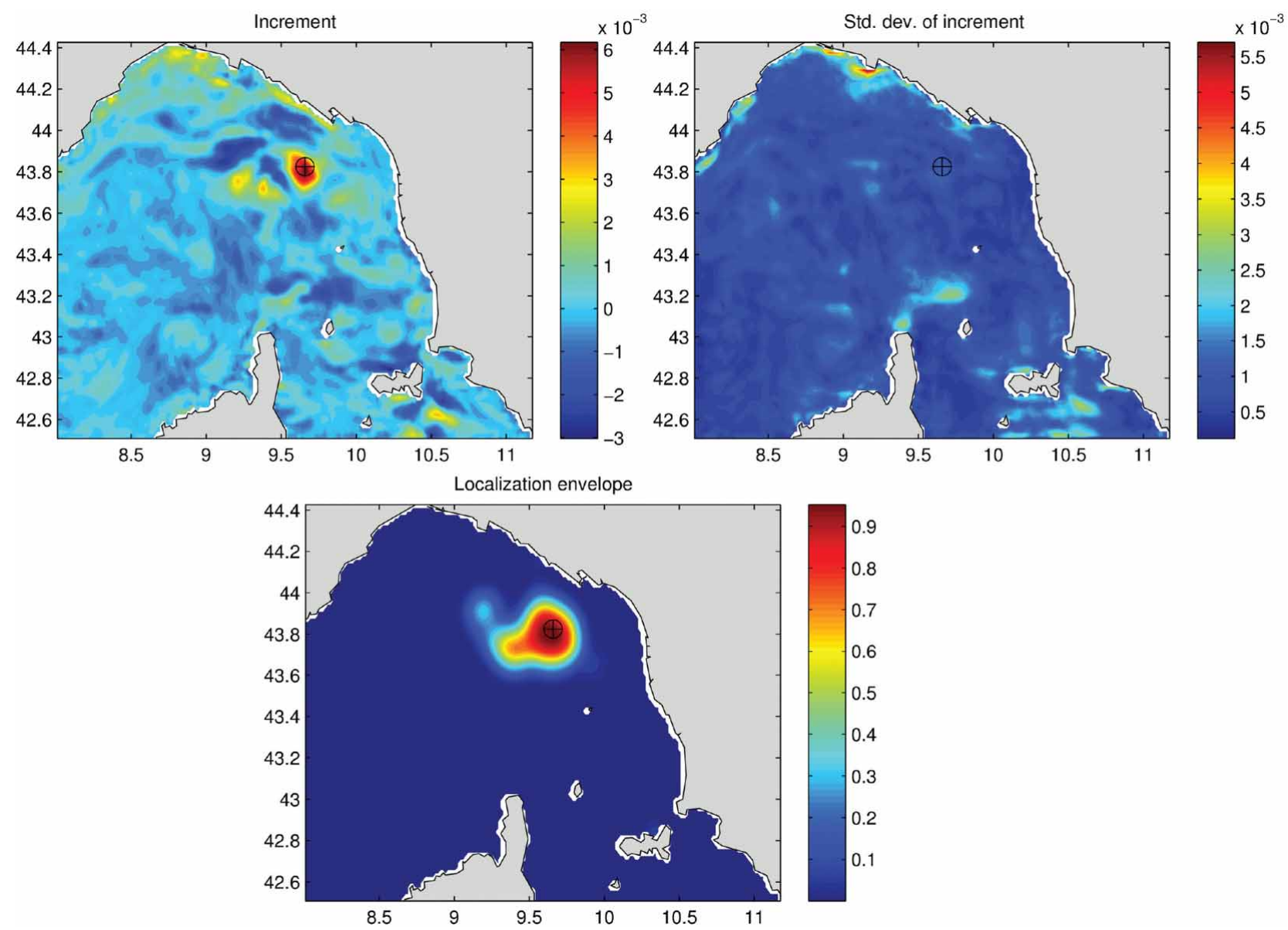

Figure 5. Example of covariance localization in the nested Ligurian Sea ROMS model. The assimilation increment obtained from the global assimilation scheme (upper left panel), standard deviation of this increment (outer Mediterranean model, upper right panel) and the resulting localization envelope using a hypothetical observation located at the position of the marker (black circle with ' $\mathrm{x}$ ' symbol at $43.8 \mathrm{~N}, 9.7 \mathrm{~W})$.

Observations assimilated during each sequence of analyses were taken from a variety of platforms and are summarized in Table 1. To illustrate the DA impact on the CCS circulation, Figure 6(a) shows the prior model SST initial conditions on 10 February 2014, while Figure 6(b) shows the corrections made to the SST prior on the same day. Figure 6(b) reveals that the SST corrections made by 4DVAR are dominated by mesoscale features of $1^{\circ} \mathrm{C}$ amplitude. Figure 7(a) shows a time series of the total number of observations available each cycle from several platforms. For WCNRT, SSH from tide gauges is included, SST is obtained only from a gridded product, and subsurface hydrography derives only from an in-situ glider (Donlon et al. 2012). Figure 7(b) shows a time series of the ratio of posterior cost function $\left(J_{f}\right)$ to the prior cost function $\left(J_{i}\right)$ for each 4DVAR from WCRA31 (WCRA14 and WCNRT are qualitatively similar), and show that 4DVAR successfully reduces $J$ by a factor of $\sim 2-3$ during each cycle. Figure $7(\mathrm{c})$ shows a time series of the kinetic energy from WCRA31, WCRA14 and a run of ROMS without DA forced using the prior forcing of WCRA31.
The kinetic energy is the average over the central California region between $34 \mathrm{~N}$ and $40 \mathrm{~N}$ from the coast to $400 \mathrm{~km}$ offshore which is a region characterized by mesoscale eddy activity (Kelly et al. 1998). Figure 7(c) illustrates that both historical analyses are significantly more energetic than the forward model alone in this region, demonstrating the influence of 4DVAR on an important, largely unobserved, component of the coastal circulation field.

\section{Coastal-scale atmosphere-wave-ocean couplings}

Oceanic flows can be strongly forced or modified by waves, in particular in the nearshore and in the coastal ocean (Longuet-Higgin 1970; Newberger \& Allen 2007b; Lentz et al. 2008). Surface waves and ocean interactions control the boundary fluxes, momentum and energy exchange between the atmosphere and the ocean and within the water column. Model coupling can be achieved at different levels of complexity. A large effort has been expended to develop models capable of resolving the vertical structure of the mean flow accounting for mixing and dispersion 

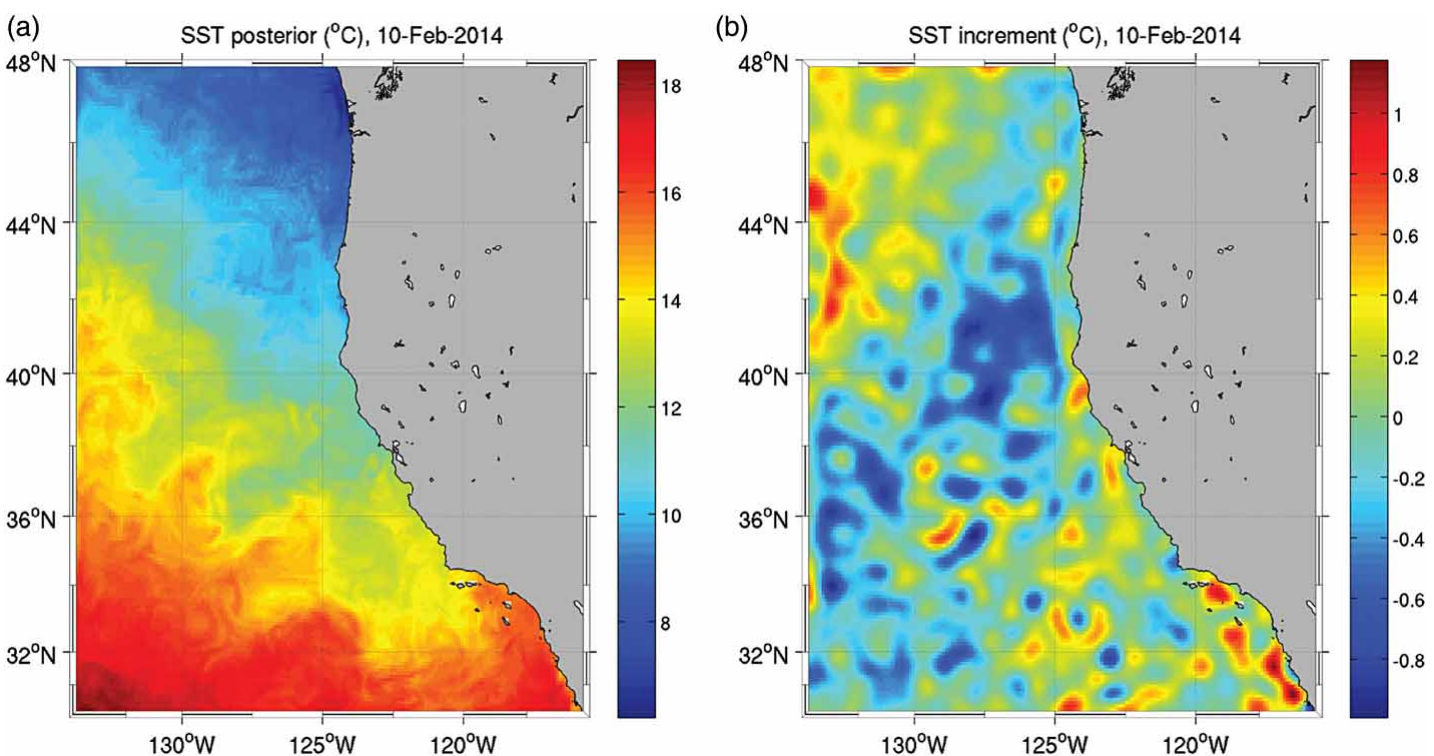

Figure 6. (a) Sea surface temperature posterior estimate on February 10, 2014 from the US West Coast Near Real Time model (WCNRT). (b) Corrections to prior model estimate of SST.
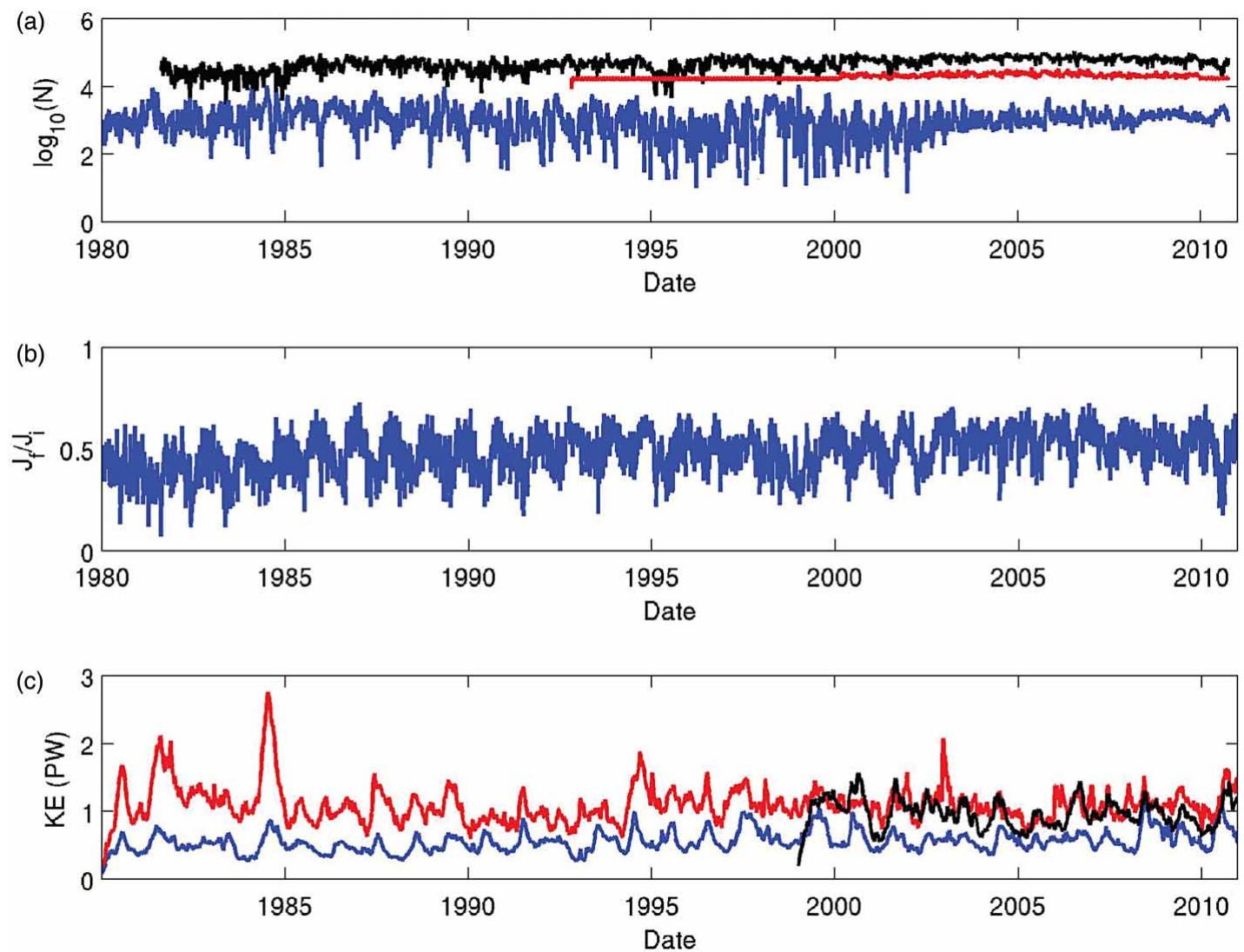

Figure 7. (a) Time series of the $\log _{10}$ of the number of observations assimilated into the West Coast Reanalyses (WCRA) models during each 4DVAR analysis cycle in the form of sea surface temperature (black curve), sea surface height (red curve) and in-situ hydographic data (blue curve). (b) A time series of the ratio of the final value $\left(J_{f}\right)$ to the initial value $\left(J_{i}\right)$ of the cost function for each 4DVAR cycle. (c) Time series of the kinetic energy off the central California coast from WCRA31 (red curve), WCRA14 (black curve) and from a forward run of the model without data assimilation (blue curve). 
keeping the hydrostatic approximation (Svendsen \& Putrevu, 1994). However, a proper representation of nearsurface currents and drift requires the introduction of wave effects, in particular the Stokes drift and waveinduced mixing (Rascle \& Ardhuin 2009).

\section{Main issues/challenges for couplings in the coastal ocean}

An important challenge in coupling coastal ocean models has been to ensure consistency in the fluxes that go between the various coupled models (atmosphere-toocean, atmosphere-to-wave, wave-to-ocean, etc.). In the uncoupled paradigm, models are calibrated and validated mostly in isolation, often with limited data compared to the number of modeled processes. As a result, dissipation terms are often used as tuning parameters to force a desired model behavior. In coupled modelling, these same dissipation terms become the fluxes to other models, e.g. the dissipated energy from wind wave models that feeds into the mixing of the upper ocean in baroclinic circulation models. This has forced the community to reassess calibration strategies when applied to coupled model systems. In the process, this has increased the need for detailed observations of processes in the model interface, which were previously neglected. It has also led to a revision of the parameterization of a number of these flux transfers between models (Mellor 2008; Tsagareli et al. 2010; Babanin et al. 2010).

\section{Examples of coupled coastal systems}

The role of the coupling of wave and circulation models on improving ocean forecasts is demonstrated for the German Bight region, characterized by wind-waves and strong tidal currents (Stanev et al. 2011). Processes like nonlinear feedback between currents and waves play an important role in this area. The coupling between the wave model (WAM) and hydrodynamical model (General Estuarine Transport Model, GETM) improves the estimates of ocean state variables, especially in coastal areas and estuaries (Stanev et al. 2003a; He et al. 2012). The coupling takes into consideration both the effect of currents on waves and the effect of waves on upper ocean dynamics (in particular on mixing and drift currents). In WAM the depth and/or current fields can be non-stationary, grid points can become dry and refraction due to spatially varying current and depth is accounted for in the quasi-stationary approach. GETM was modified to account for wave effects by introducing the depth dependent radiation stresses and Stokes drift. These terms were calculated from the integrated wave parameters (Mellor 2008). The gradient of the radiation stresses serves as an additional explicit wave forcing term in the momentum equations for the horizontal velocity components. The transfer of momentum by waves becomes important for the mean water level setup and for the alongshore currents generated by waves in the surf zone.

The role of coupling is demonstrated by analyzing the impact of waves on extreme events (storm Xavier, Figure 8). The radiation stress increases the average water levels, a pronounced effect in the coastal area. During normal conditions, the differences of the sea level due to the coupling with the wave model are maximum $10-15 \mathrm{~cm}$ around the Elbe estuary. However, during the storm, the differences of simulated sea level when considering waves are about $30-40 \mathrm{~cm}$ along the whole German coast. Therefore, the uncertainties in most of the presently used models result from the nonlinear feedback between strong tidal currents and wind-waves, which can no longer be ignored in the operational oceanography, particularly in the coastal zone where its role seems to be dominant.

Several other studies demonstrate the importance of wave current coupling in the coastal regions (e.g. for the NW Meditteranean) and for the Liverpool Bay (Jordà et al. 2007; Bolaños et al. 2011; Brown et al. 2011). In the framework of MyOcean European project http:// Myocean.eu, a growing effort has been devoted to wave and primitive equation models coupled in regional systems. For instance, in the Mediterranean Forecasting System (MFS) the wave and ocean models are tightly coupled to improve the representation and forecast of wave parameters and the oceanic mean flow (Oddo et al. 2009). The coupled (WW3-NEMO) operational MFS improves the already good results achieved by the standalone wave model and primitive equation model, and is able to provide the large scale information needed for the nested coastal systems. Similar efforts in the US are through NOAA's Integrated Ocean Observing System [IOOS; http://www.ioos.noaa.gov/].

Another recent effort is based on deploying a fully coupled ocean/air/wave modelling system within the Earth System Modelling Framework (ESMF) to complete the US Navy's COAMPS, a globally relocatable modelling system designed for operational time (days) and space ( 1$10 \mathrm{~km}$ ) scales (Allard et al. 2014). Test cases with the wave model component are being completed as the final phase of transition to operations. Such systems can enhance existing regional models by elucidating mechanisms that may be missing or not properly accounted for in local coastal forecasting systems. COAMPS has been deployed recently for island regions with steep terrain to elucidate the mechanisms of wind-induced oceanic eddy formation and detachment in the Philippines (Pullen et al. 2008; Pullen et al. 2011; May et al. 2011; Rypina et al. 2010). In a similar vein, the air-sea coupled model has been applied to the island of Madeira. A real-time forecasting system http:// wakes.uma.pt consisting of high-resolution MM5 (now WRF) and ROMS has been operational since 2007. But such a one-way coupled system was unable to reproduce the warm wake effect whereby the cloud-free region in 

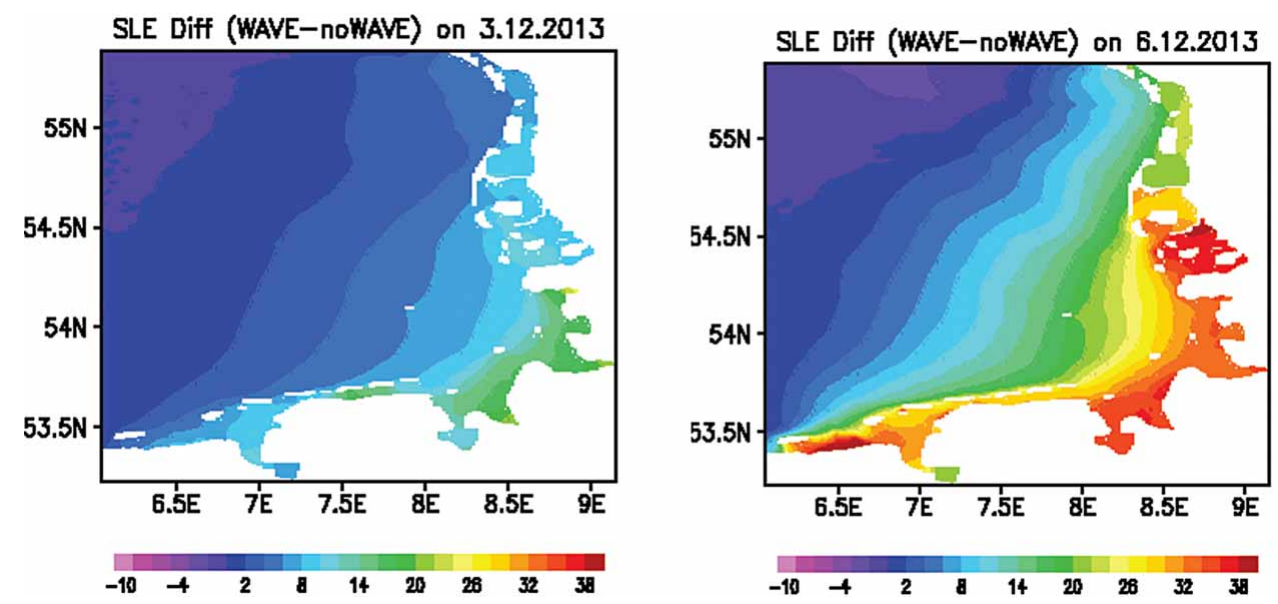

Figure 8. Sea surface elevation (SLE) difference between coupled wave-circulation model (WAM-GETM) and the pure circulation model (GETM) for the German Bight on 3 December 2013 (left) and during the storm Xavier on 6 December 2013 (right).

the lee of the island leads to enhanced ocean temperatures (Sachsperger 2012; Caldeira \& Tome 2013). A recent application of the two-way coupled air/sea COAMPS system is able to capture the evolution of the warm wake in the lee of Madeira in both the upper ocean and lower atmospheric boundary layer.

\section{Coastal ecosystem response to the physical drivers}

The coastal and shelf seas are among the world's most diverse and productive environments and an important component of the marine environment, accounting for up to $30 \%$ of the ocean's primary production, hosting major fisheries of the world, and may be important in global carbon budgets (Gattuso et al. 1998; Smith \& Hollibaugh 1993; Longhurst et al. 1995; Edwards et al. 2012; Pauly \& Christensen 1995; Pauly et al. 2002; Holt et al. 2009). These factors pose urgent needs for expanding beyond the forecasting of physical variables.

\section{Biogeochemical prediction in the coastal seas}

Better understanding of the state of shelf sea ecosystems requires the implementation of coupled hydrodynamic and ecosystem models at regional/coastal high-resolution scales. Uncoupled ecosystem models have been developed for a wide range of applications: (a) process-oriented studies on shelf seas biogeochemical cycles, nutrient fluxes and pathways; (b) understanding of the effects of eutrophication; (c) hypoxia; (d) harmful algal blooms (HABs), etc. (Proctor et al. 2003; Nobre et al. 2005; Yakushev et al. 2007; Russo et al. 2009; McGillicuddy, 2010). Coupled three-dimensional hydrodynamic-ecosystem models are able to simulate the biogeochemistry of coastal ecosystems but they can also advance knowledge on the ecosystem functioning (Moll \& Radach 2003). Several coupled model systems have helped establish the critical climatological, seasonal and interannual aspects of ecosystem variability, while also used to explore alternate states under different management scenarios (Hofmann \& Lascara 1998; Crise et al. 1999; Brown et al. 2013; Dabrowski et al. 2014; Wild-Allen et al. 2010; Holt et al. 2012). Coupled model systems help address the variability of the marine ecosystems and their response to the variability of physical forcing. Ventilation processes and circulation overturning determine the supply of waters with nutrients and support primary production. In favorable wind conditions, the upwelling in coastal areas due to Ekman transport is a mechanism providing nutrient rich waters at the surface and favoring primary production. Changes in the ocean circulation and stratification trigger the changes of the mixed layer depth and consequently of the nutrient levels at the ocean which also has a response to the primary production (Sarmiento et al. 2004).

The winter convection triggered by air-sea exchange is also an important process for the physical impact on the ecosystem (Stanev et al. 2003b). Convective mixing is also highly influenced by the changes of the thermocline and halocline, and hence, changing the amount of nutrient available for phytoplankton growth. Another important physical driver is the freshwater river input that influences both stratification and the coastal circulation. Examples include the US west coast, the US east coast, the northern Gulf of Mexico, the Western South Atlantic shelf, the greater Caribbean, the Adriatic and Aegean Seas and the north-western Black Sea, to name a few (Kourafalou et al. 1996; Kourafalou 2001; Hu et al. 2004; Soares et al. 2007; Tsiaras et al. 2008; Hickey et al. 2010; Androulidakis \& Kourafalou 2013). The combination of physical and biogeochemical modelling is also important when addressing connectivity between ocean and coastal areas and among remote coastal ecosystems. Such phenomena are crucial for the understanding populations (as in coral reef habitats (Sponaugle et al. 2012)), the design of 
Marine Protected Areas and the management of the world's fisheries.

Finally, the contribution of benthic nutrient fluxes to the total nutrient pool available for primary production uptake increases, as water depth decreases approaching the coast. Sediment layers in biogeochemical models, where remineralisation of nutrients and exchange with the overlying water column occurs, become increasingly important. This also forms the backbone for modelling sediment transport, which is a separate discipline delivering specific products to end users (e.g. deposition and re-suspension maps, sedimentation rate, fate of dredging activities).

\section{Examples of coastal interdisciplinary systems}

The interest in combined physical, chemical and biological operational products, including near-real time and forecast is increasing. Internationally implemented marine policies, aimed at protecting the sea from increasing environmental pressures, have shown the need for monitoring marine systems. In the European Union, the Water Framework Directive and the Marine Strategy Framework Directive (MSFD) are dealing with an evaluation and monitoring of the ecological status of their river basins/coastal waters and marine waters (Borja et al. 2006). Additionally, the European Marine Ecosystem Observatory EMECO, www.emeco-group.org was formed in response to new challenges posed by the MSFD and the implicit need to deliver an ecosystem-based management approach. The IOOS national network of Regional Coastal Ocean Observing Systems (RCOOS) in the US has implemented biophysical forecasts to satisfy national needs (Kourafalou et al. 2015). However, ecosystem modelling remains a highly complex and challenging task. Biogeochemical models are built on many assumptions and often empirical-based parameterizations; identifying an appropriate set of parameters through trial runs is seldom straightforward (Marta-Almeida et al. 2012). The strong dependency of biology on physical drivers also requires reliable nearreal time coastal ocean circulation forecasts.

The coupled hydrodynamic-ecosystem model by the UK's Met Office provides forecasts from the Medium-Resolution Continental Shelf POLCOMS-ERSEM system to the $7 \mathrm{~km}$ Atlantic Margin Model NEMO-ERSEM system (Siddorn et al. 2007). The ecosystem components in the operational system are also validated against available insitu, satellite and climatological data. Other regions in Europe with operational modelling products for biology (all available through http://www.myocean.eu/) are the Baltic Sea and the Mediterranean Sea, with Eastern (POSEIDON) and Western basin sub-systems (Neumann 2000; Nittis et al. 2001; Borja et al. 2006; Lazzari et al. 2010).

A more extensive example is provided for the Black Sea (Figure 9), the world's largest marine anoxic basin
(Murray et al. 1989). Anoxic conditions formed about 8,000 years ago following the reconnection of the Mediterranean and Black Seas and the resulting intrusion of saltier Mediterranean water (Deuser 1974). The vertical structure is represented by an oxygenated surface layer and a sulfide containing deep layer, separated by the suboxic zone (Murray et al. 1989; Murray et al. 1995)

The deployment of two ARGO floats in the northern Black Sea in 2010 enabled, for the first time, more than 2-year continuous observations (Figure 9). The Navigating European Marine Observer (NEMO) profilers were equipped with temperature, salinity and oxygen sensors (see trajectories in Figure 9) (Stanev et al. 2013). As the two floats operated in two dynamically very different areas, the open ocean and the coastal zone, it was a unique opportunity to compare synchronously the differences between changes of hydro-chemistry in these different zones and to evaluate biophysical model predictive capabilities. The coastal float NEMO-0145 revealed vigorous changes of oxygen, manifesting the importance of the mesoscale processes for the oxygen change. The observed oxygen variability gave clear indication that its distribution was a function of the general circulation characterized by an upward motion in the basin interior and sinking in the areas of coastal anticyclones. Extremely low temperature, as well as high oxygen concentrations, caused by the abnormally cold winter, persisted along the southern coast (February-July 2012). The correlation between time versus depth oxygen and temperature diagrams demonstrated that mesoscale eddies contributed largely to the variations of oxygen (Stanev et al. 2013).

A model-to-data comparison in the temporal variability of the upper layer oxygen is illustrated through the oxygen versus temperature relationships (Figure 9). These profiles are characterized by almost vertical curves in the late fall and beginning of winter, i.e. with a relatively homogeneous oxygen distribution in the cold season. The lowest oxygen values at sea surface approached $250 \mu \mathrm{M}$ both in the model and observations. The warming of surface waters was accompanied by a decrease in the surface-oxygen concentration and the formation of oxygen subsurface maximum. This excluded the possibility that subsurface oxygen maximum was just a direct result of oxygen-rich water created by winter convection that remained overlaid in summer by low oxygen surface water (because of the high SST). The model was thus able to replicate almost all observed features of the oxygen dynamics, making it a useful tool for investigating the upper-ocean hydrochemistry of the Black Sea.

\section{Utility of coastal systems}

The combination of coastal ocean observations and models provides a powerful tool for describing and understanding complex ocean system interactions. By combining 


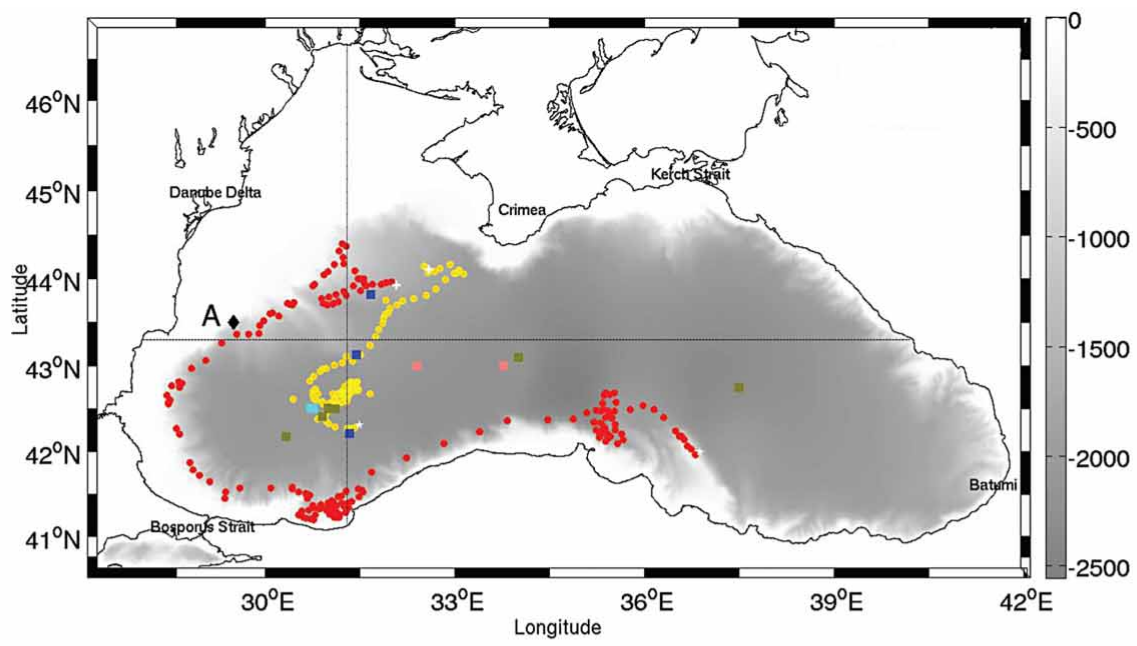

(a)

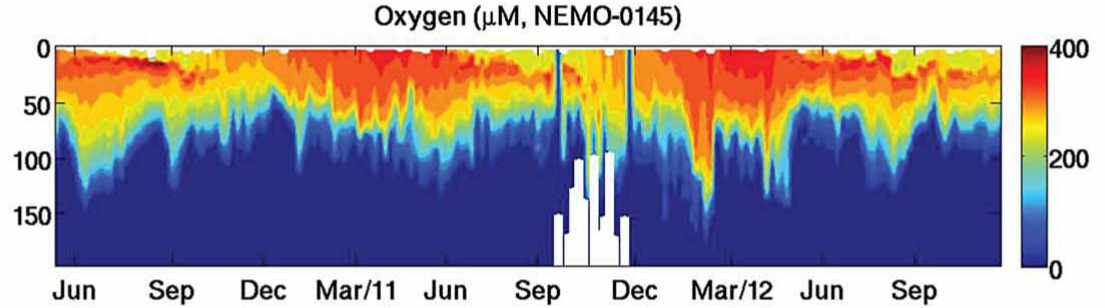

(b)

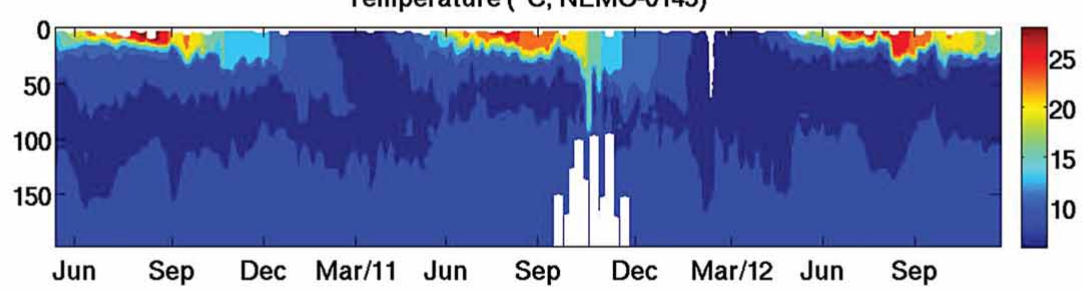

(a)

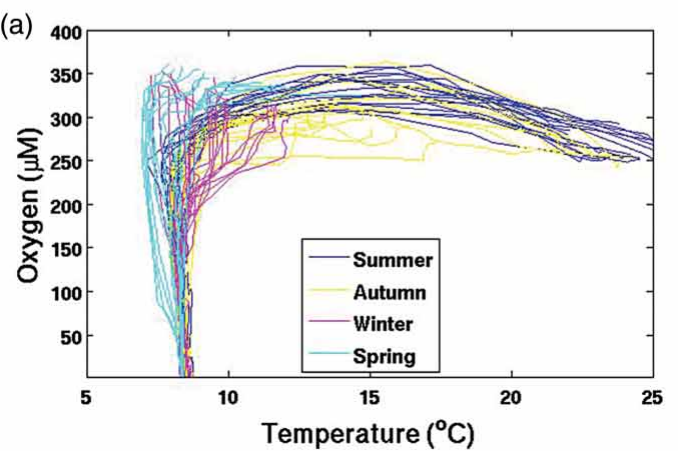

(b)

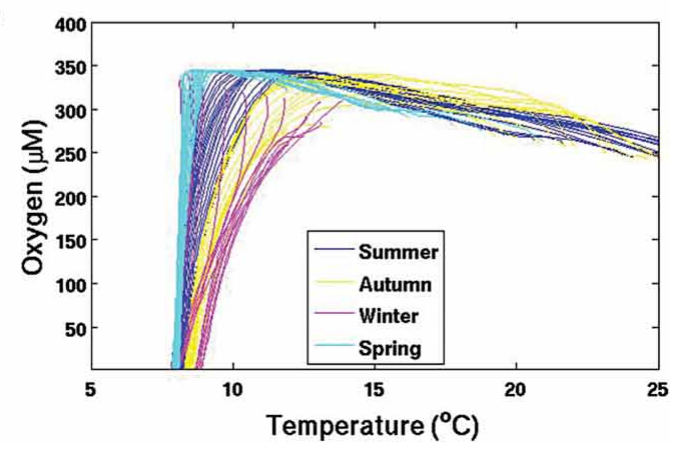

Figure 9. (Top): Black Sea topography and float trajectories. Locations of Argo floats surfacing are shown with yellow (NEMO-0144) and red (NEMO-0145). Deployment positions are marked by crosses, the last positions are labeled by stars. Squares in different colors show the observed positions where historical data have been analyzed. (Middle) Time versus depth plots of (a) oxygen and (b) temperature as observed by the coastal Argo float NEMO-0145. (Bottom) Model to data comparison using oxygen versus temperature plots in location 'A' for the four seasons: (a) observational seasonal profiles from the coastal Argo float (NEMO-0145) data and (b) simulated seasonal profiles from the 3D biophysical model.

science-based observations with well-constructed models, advances can be made toward understanding complex coastal ocean systems and development of useful tools for managing coastal ocean resources. Applications are closely linked to the science foundation behind the physical drivers, giving feedback that provides exciting new scientific 
challenges. Their fundamental utility is addressing broad societal and economic benefits and needs; examples follow.

The Central and Northern California Coastal Ocean Observing System (CeNCOOS) is supported by both the near real-time analyses and historical analyses (outputs available at http://oceanmodelling.ucsc.edu/; http://www. cencoos.org/). Like other regional observatories, CeNCOOS provides ocean information for effective management of coastal waters, such as ecosystem-based management of marine fisheries, understanding impacts of climate change, and assessing coastal water quality issues such as Harmful Algal Blooms. Among current users of the ROMS CCS 4DVAR analyses described in the previous section are fisheries scientists whose goals are to relate oceanographic conditions with larval survival and recruitment data for commercially-relevant fisheries on the US west coast.

Understanding processes in coastal ocean ecology that can improve biophysical predictions and aid the management of coastal resources is another application of interdisciplinary coastal systems. A recent example is from the West Florida Shelf. Observations of velocity from moorings, water properties from glider transects, satellite imagery and $K$. brevis cell counts were combined with model simulations from the WFCOM (see previous section) to explain why there was no red tide on the west Florida shelf in 2010 (Weisberg et al. 2014a). It was concluded that both the physics of the circulation and the biology of the organism are necessary conditions for a $K$. brevis bloom to occur, but neither alone are sufficient conditions. In another study that similarly combined multidisciplinary observations with model simulations, the conundrum of how grouper larvae get from offshore adult spawning to near shore juvenile settlement sites was addressed (Weisberg et al. 2014b). Another study deals with connectivity patterns, important for understanding coral fish replenishment and aiding the management of reef resources. A high resolution biophysical model around the Southwest Florida Shelf and the Florida Keys was used, in tandem with detailed observations for model evaluation and calibration, to construct connectivity matrices for coral fish larvae (Sponaugle et al. 2012).

Maritime Domain Awareness (MDA) has benefitted from an infusion of tools and technologies, and has been an active area of planning and policy in the homeland security enterprise. Partnerships and data integration are an increasingly important aspect of maritime security and law enforcement mission areas, including illegal fishing interdiction and search and rescue. Linking coastal forecasts to search and rescue decision support tools is an effective strategy to reduce search times and better allocate ships and airborne assets (Breivik et al. 2013). For instance, the US Coast Guard is increasingly focused on domains such as the Arctic and island environments, where they must be able to carry out their traditional missions in challenging conditions. Saving time and resources in such environments is extremely important. The use of coastal forecasting for Coast Guard missions will provide even more benefits in harsh operating environments where observations may be limited and coastal forecasts can contribute vital situational information.

An operational search and rescue (SAR) modelling system has been developed to forecast the tracks of victims or debris from marine accidents in the marginal seas of the northwestern Pacific Ocean (Cho et al. 2014). The SAR system is directly linked to a real-time operational forecasting system that provides $72 \mathrm{~h}$ wind and surface current forecasts for the Yellow Sea and the East and South China Seas, capable of predicting the tracks and area to be searched. The SAR modelling system is used operationally to support the Korea Coast Guard during marine emergencies. Such applications often extend to ship routing operations. While the use of weather forecast data (wind and waves) in the optimization of ship routing is more common, the incorporation of surface current information is still a challenge (Panigrahi et al. 2012; Lin et al. 2013). Focusing on the Kuroshio region, the impact of using the current or avoiding it (when travelling in the opposite direction) for reducing the transit time of ships has been demonstrated (Chang et al. 2013). For instance, using a combination of weather and ocean simulations for the Osaka Bay region (Japan), a case study evaluates the effectiveness of each forcing for optimizing the ship route (Chen et al. 2013).

As ports compete for business, shipping and cruise lines assume the responsibility of added security, and high value waterfront assets require protection, MDA approaches and solutions will continue to expand in both the public and the private sectors. With the advent of technologies and procedures focused on maritime security, there is a strong role for coastal forecasting modelling to contribute to optimal performance of these security and safety-focused systems. For instance, sensor networks require information on the current and projected environmental operating conditions in order to estimate performance characteristics. Acoustic monitors for underwater and surface threat detection (small vessels, scuba divers, small submarines, etc.) use sound propagation to detect targets. Linking coastal forecasts of temperature and salinity to transmission loss models can produce detailed maps of where targets could hide or detection systems should be augmented. In addition, detection systems are increasingly complex with components consisting of acoustic sensors, radar, and cameras (Pullen \& Bruno 2014). In order to promote optimal performance, sensors need to be able to cue each other to examine targets or turn on/off during different operating conditions so that the best performing sensor, given the particular coastal conditions, is operating. This paradigm represents a smart implementation of sensors joined with high-resolution, 

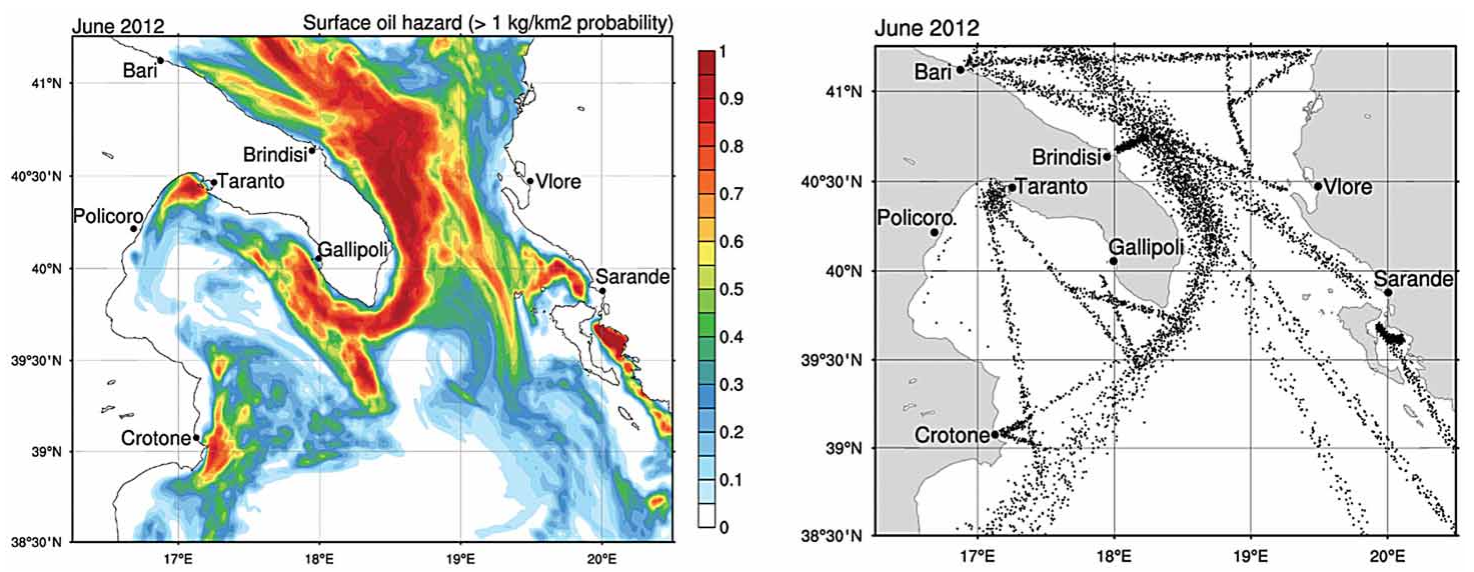

Figure 10. Monthly averaged surface oil hazard maps $\left(>1 \mathrm{~kg} / \mathrm{km}^{2}\right.$ probability of oil presence) in the southern Adriatic Sea (left panel) and ship line distribution (right panel) over the same area during June 2012.

accurate coastal forecasts and suggests another way in which coastal ocean forecasting can enhance maritime domain awareness.

Modelling the transport and fate of hydrocarbons resulting from oil spills is another example of the utility of coastal prediction systems. The major 2010 oil spill accident from the Macondo well in the Gulf of Mexico has attracted a large number of efforts to improve predictive capabilities in a complex regional sea, which is subject to intense ocean exploration form the oil and gas industries. Several immediate applications were made at the time of the spill (Mezic et al. 2010; Liu et al. 2011; Mariano et al. 2011; Weisberg et al. 2011). Subsequent analyses expand on the need for downscaling to improve the interactions between basin-wide (i.e. the Gulf Stream) and coastal currents (i.e. wind-driven and buoyancy-driven currents and intense slope exchanges) for tracking the oil and exploring its environmental consequences (Paris et al. 2012; Le Hénaff et al. 2012; Kourafalou et al. 2013; Weisberg et al. 2014c). Two of the main uses of operational ocean numerical modelling are monitoring and forecasting of marine pollution and impacts of offshore activities (Hackett et al. 2009).

The complexity of the oil tracking models and their dependence on the oceanic and atmospheric forecasts has also been shown (Marta-Almeida et al. 2013b). European operational models are being extended with the ability to predict the behavior and evolution of an oil spill in the marine environment and linking it to an online risk assessment/contingency response tool available for stakeholders (Janeiro et al. 2012). Within the IONIO (Ionian integrated Marine Observatory, www.ionioproject.eu) project, in support of coastal management, a Pollution Hazard Mapping Decision Support System has been developed. Hazard mapping (Figure 10) appears as the most appropriate way to approach the management of oil pollution in marine areas in order to sustain the ecosystem health state. The methodology integrates the ship traffic data with the data on currents and temperature from the Operational Modelling System together with the fate and transport oil spill model (MEDSLIK-II) (De Dominicis et al. 2013).

Coastal wave and storm surge modelling has significant benefits to coastal communities. These communities are increasingly vulnerable to powerful land falling hurricanes and extra-tropical storms, and need guidance on how to prepare for, and respond to water-related calamities. In the US, operational guidance from storm surge and inundation models such as the SLOSH-based P-Surge and the ADCIRC-based ESTOFS are used to inform emergency managers on whether or not to evacuate coastal regions ahead of storm events (Feyen et al. 2013). Similar models are applied in hindcast mode to assess risks in hurricane preparedness and insurance studies.

In itself, detailed nearshore wave guidance, provided in the US by NOAA's Nearshore Wave Prediction System (NWPS), has a number of applications in the commercial and recreational coastal waters. Accurate forecasts of wave conditions in coastal regions and in entrance channels and inlets, especially under the influence of steepening currents, are critical to safety of life at sea. In terms of recreational activities, the leading cause of beach drowning in the US is rip currents. An operational rip current prediction system has been successfully prototyped within NWPS, showing high skill compared to recorded rip current sightings (Dusek \& Seim 2013; Dusek et al. 2014).

\section{Conclusions}

Advancement of forecasting in coastal and shelf seas requires continuous development of innovative methodologies and tools, in support of research and applications. The magnitude of the sampling problem and the short 
space and time scales preclude ever having enough observations to fully describe the coastal ocean. Coastal Ocean Forecasting Systems (COFS) that integrate observatories with models are thus required, working in synergy to assess and predict coastal phenomena of interest and satisfy the needs of well-defined users. Within GODAE OceanView, the COSS-TT promotes international collaboration in addressing all scientific issues related to COFS needs and downstream applications, aiming to promote a seamless framework of observations and data assimilative models from the global to the coastal/littoral scale.

Coastal ocean models in COFS require dedicated numerical techniques for both individual ocean components and fully coupled models. A primary science topic is downscaling from larger scale models, toward the development of appropriate nesting procedures. These include assessment of the boundary conditions provided to COFS nested systems from larger scale systems, and refinement of model set-up (including grids, topographic details and forcings). Other primary topics driving COFS research and development were discussed, especially issues associated with model coupling and data assimilation in the coastal ocean, including assessment of model errors. A challenge for coupling is to ensure consistency in the fluxes between the modelling components. For data assimilation, challenges arise due to the relative importance of the boundary conditions compared to the initial conditions, and due to anisotropic processes in the coastal zone. It was highlighted that the above physical drivers have a pronounced impact on coastal ecosystem functioning and connectivity among remote ecosystems.

Benefits from scientific and technical advances associated with COFS encompass a wide range of socioeconomic aspects. These include: environmental studies required for permits and oversight for the management of marine resources, construction, oil/gas exploration, insurance claims etc.; sea treaties and agreements (regulation of natural resources, marine pollution litigation, regional fish stock management, Marine Protected Areas, United Nations Convention on the Law of the Sea/UNCLOS, etc.); recreational and commercial fishing; search and rescue; Maritime Domain Awareness; mitigation of natural disasters, climate change and extreme events; predictions on the transport and fate of pollutants. Advancements in COFS will further develop consistent protocols for observation impact assessment, tools for routine production of appropriate diagnostics, common sets of metrics for inter-comparison of results, and objective methodologies for observing system design and assessment activities.

\section{Acknowledgements}

V. Kourafalou acknowledges NOAA support (NA13OAR 4830224 and NA12OAR4310073) and H. Kang (UM/RSMAS) for help with manuscript formatting. P. De Mey and N. Ayoub have closely collaborated with P. Marsaleix (CNRS/LA, France) and have been supported from CNES through the Ocean Surface Topography/Jason project MICSS and from CNRS/ INSU. A. Barth was supported in part by the National Fund for Scientific Research, Belgium (F.R.S.-FNRS) and the SANGOMA project (FP7-SPACE-2011-1-CT-283580SANGOMA). The research by Y. Chao was supported by NOAA/IOOS (through CeNCOOS, SCCOOS) and the NASA Interdisciplinary Science program. M. Herzfeld is thankful to the eReefs marine modelling team and partners (CSIRO: Commonwealth Industrial and Scientific Research Organization; SIEF: Science and Industry Endowment Fund; AIMS: Australian Institute of Marine Science). A. Moore acknowledges support from the US National Science Foundation (OCE 1061434) and by NOAA/IOOS through CeNCOOS. R.H. Weisberg was assisted by $\mathrm{L}$. Zheng and both were supported in part by the BP/The Gulf of Mexico Research Initiative through the Deep-C Program hosted at the Florida State University.

\section{References}

Allard R, Rogers E, Martin P, Jensen T, Chu P, Campbell T, Dykes J, Smith T, Choi J, Gravois U. 2014. The US Navy Coupled Ocean-Wave Prediction System. Oceanography. 27(3): 92103, http://dx.doi.org/10.5670/oceanog.2014.71

Androulidakis YS, Kourafalou VH. 2013. On the processes that influence the transport and fate of Mississippi waters under flooding outflow conditions. Ocean Dyn. 63(2-3): 143-164.

Auclair F, Marsaleix P, De Mey P. 2003. Space-time structure and dynamics of the forecast error in a coastal circulation model of the Gulf of Lions. Dyna Atmos Oceans 36: 309-346, doi:10. 1016/S0377-0265(02)00068-4.

Auclair F, Marsaleix P, Estourne C. 2001. The penetration of the Northern Current over the Gulf of Lions (Mediterranean) as a downscaling problem. Oceanol Acta. 24(6): 529-544.

Babanin AV, Tsagareli KN, Young IR, Walker DJ. 2010. Numerical Investigation of Spectral Evolution of Wind Waves. Part II: Dissipation Term and Evolution Tests. J Phy Oceanogr. 40: 667-683.

Barth A, Alvera-Azcárate A, Beckers J-M, Rixen M, Vandenbulcke L. 2007. Multigrid state vector for data assimilation in a two-way nested model of the Ligurian Sea. J Mar Syst. 65: 41-59, doi:10.1016/j.jmarsys.2005.07.006.

Bennett AF. 2002. Inverse Modelling of the Ocean and Atmosphere. Cambridge, University Press, 234pp.

Blumberg AF, Kantha LF. 1985. Open boundary condition for circulation models. J Hydraul Eng. 111: 237-255.

Bolaños R, Osuna P, Wolf J, Monbaliu J, Sanchez-Arcilla A. 2011. Development of the POLCOMS-WAM current-wave model. Ocean Model. 36(1-2): 102-115.

Borja and co-authors.. 2006. The European Water Framework Directive and the DPSIR, a methodological approach to assess the risk of failing to achieve good ecological status. Estuarine, Coastal and Shelf Science 66: 84-96.

Breivik Ø, Allen AA, Maisondieu C, Olagnon M. 2013. Advances in Search and Rescue at Sea. Ocean Dyn. 63: 83-88, doi:10. 1007/s10236-012-0581-1.

Brinkman RM, Wolanski EJ, Deleersnijder E, McAllister FA, Skirving WJ. 2002. Oceanic inflow from the Coral Sea into the Great Barrier Reef. Estuarine Coastal and Shelf Science 54: 655-668.

Brown CW, Hood RR, Long W, Jacobs J, Ramers DL, Wazniak C, Wiggert JD, Wood R, Xu J. 2013. Ecological forecasting in 
Chesapeake Bay: Using a mechanistic-empirical modelling approach. J Mar Syst. 125: 113-125.

Brown J, Bolaño R, Wolf J. 2011. Impact assessment of advanced coupling features in a tide-surge-wave model, POLCOMSWAM, in a shallow water application. J Mar Syst. 87(1): $13-24$.

Burrage DM, Church JA, Steinberg CR. 1991. Linear systems analysis of Momentum on the continental shelf and slope of the Central Great Barrier Reef. J Geophys Res. 96(C12): 22169-22190.

Cailleau S, Fedorenko V, Barnier B, Blayo E, Debreu L. 2008. Comparison of different numerical methods used to handle the open boundary of a regional ocean circulation model of the Bay of Biscay. Ocean Model. 25: 1-16.

Caldeira R, Tome R. 2013. Wake Response to an Ocean-Feedback Mechanism: Madeira Island Case Study. Bound-Lay Meteorol. 148(2): 419-436.

Chang Y-C, Tseng R-S, Chen G-Y, Chu P C, Shen Y-T. 2013. Ship Routing Utilizing Strong Ocean Currents. The Journal of Navigation 66: 825-835.

Chao Y, Li Z, Farrara J, McWilliams C, Bellingham J, Capet X, Chavez F, Choi J-K, Davis R, Doyle J, et al. 2009. Development, implementation and evaluation of a dataassimilative ocean forecasting system off the central California coast. Deep-Sea Res II. 56: 100-126.

Chao Y, Li Z, Farrara JD, Moline MA, Schofield OME, Majumdar SJ. 2008. Synergistic applications of autonomous underwater vehicles and the regional ocean modelling system in coastal ocean forecasting. Limnol Oceanogr. 53: 2251-2263.

Chassignet EP, Hurlburt HE, Metzger EJ, Smedstad OM, Cummings J, Halliwell GR, Bleck R, Baraille R, Wallcraft AJ, Lozano C, Tolman H, Srinivasan A, Hankin S, Cornillon P, Weisberg R, Barth A, He R, Werner C, Wilkin J. 2009. U.S. GODAE: Global Ocean Prediction with the HYbrid Coordinate Ocean Model (HYCOM). Oceanography 22: 48-59.

Chen C, Shiotani S, Sasa K. 2013. Numerical ship navigation based on weather and ocean simulation. Ocean Eng. 69: 44-53.

Chen CS, Liu H, Breadsley RC. 2003. An unstructured, finitevolume, three-dimensional, primitive equation ocean model: application to coastal ocean and estuaries. J Atmos Ocean Tech. 20: 159-186.

Cho K-H, Li Y, Wang H, Park K-S, Choi J-Y, Shin K-I, Kwon J-I. 2014. Development and Validation of an Operational Search and Rescue Modelling System for the Yellow Sea and the East and South China Seas. J Atmos Ocean Tech. 31: $197-215$.

Crise and co-authors.. 1999. The Mediterranean pelagic ecosystem response to physical forcing. Prog Oceanogr. 44: 219243.

Dabrowski T, Lyons K, Berry A, Cusack C, Nolan G D. 2014. An operational biogeochemical model of the North-East Atlantic: Model description and skill assessment. J Mar Syst. 129: 350 367.

De Dominicis M, Pinardi N, Zodiatis G, Archetti R. 2013. MEDSLIK-II, a Lagrangian marine surface oil spill model for short-term forecasting - Part 2: Numerical simulations and validations. Geoscientific Model Developmen 6: 18711888, doi:10.5194/gmd-6-1871-2013.

De Mey P and co-authors.. 2009. Applications in Coastal Modelling and Forecasting. Oceanography 22(3): 198-205.

Debreu L, Blayo E. 2008. Two-way embedding algorithms: a review. Ocean Dyn. 58: 415-428.
Debreu L, Marchesiello P, Penven P, Cambon G. 2012. Two-way nesting in split-explicit ocean models: Algorithms, implementation and validation. Ocean Model. 49-50: 1-21.

Deuser WG. 1974. Evolution of anoxic of anoxic conditions in the Black Sea during Holocene. The Black Sea-Geology, Chemistry and Biology 2: 133-136.

Dobricic S, Pinardi N, Adani M, Tonani M, Fratianni C, Bonazzi A, Fernandez V. 2007. Daily oceanographic analyses by Mediterranean Forecasting System at the basin scale. Ocean Sci. 3: 149-157.

Dombrowsky E, Bertino L, Brassington GB, Chassignet EP, Davidson F, Hurlburt HE, Kamachi M, Lee T, Martin MJ, Mei S, Tonani M. 2009. GODAE systems in operation. Oceanography 22(3): 80-95.

Donlon CJ, Martin M, Stark JD, Roberts-Jones J, Fiedler E, Wimmer W. 2012. The Operational Sea Surface Temperature and Sea Ice analysis (OSTIA). Remote Sens Environ. doi:10.1016/j.rse.2010.10.017.

Doyle JD, Jiang Q, Chao Y, Farrara J. 2009. High-resolution realtime modelling of the marine atmospheric boundary layer in support of the AOSNII field campaign. Deep-Sea Res II. 56: 87-99.

Dusek G, Seim H. 2013. A probabilistic rip current forecast model. J Coastal Res. 29(4): 909-925.

Dusek G, van der Westhuysen AJ, Gibbs A, King D, Kennedy S, Padilla R, Seim H, Elder D. 2014. Coupling a Rip Current Forecast Model to the Nearshore Wave Prediction System. To appear in Proc. 94rd AMS Annual Meeting, Atlanta, GA.

Edwards P, Barciela R, Butensch M. 2012. Validation of the NEMO-ERSEM operational ecosystem model for the North West European Continental Shelf. Ocean Sci. 8: 9831000. www.ocean-sci.net/8/983/2012/doi:10.5194/os-8-9832012.

Errico RM, Vukićević T. 1992. Sensitivity analysis using an adjoint of the PSU-NCAR mesoscale model. Mon Weather Rev. 120: 1644-1660.

Evensen G. 2003. The Ensemble Kalman Filter: theoretical formulation and practical implementation. Ocean Dyn. 53: 343-367, doi:10.1007/s10236-003-0036-9.

Feyen JC, Funakoshi Y, van der Westhuysen AJ, Earle S, Caruso Magee C, Tolman HL, Aikman FIII. 2013. Establishing a Community-Based Extratropical Storm Surge and Tide Model for NOAA's Operational Forecasts for the Atlantic and Gulf Coasts. Proc. 93rd AMS Annual Meeting, Austin, TX.

Flather RA. 1988. A numerical investigation of tides and diurnalperiod continental shelf waves along Vancouver Island. J Phys Oceanogr. 18: 115-139.

Frankignoulle M, Bourge I, Romaine S, Buddemeier RW. 1998. Effect of calcium carbonate saturation of sea-water on coral calcification. Global and Planetary Change 18: 37-46, doi:10.1016/S0921-8181(98)00035-6.

Gattuso J-P and co-authors. 1998. Seawater carbonate chemistry and calcification rate of colonies of Stylophora pistillat. doi:10.1594/PANGAEA.761768, Supplement to: Gattuso JP;

Guillou N, Chapalain G, Duvieilbourg E. 2013. Sea surface temperature modelling in the Sea of Iroise: assessment of boundary conditions. Ocean Dyn. 63(7): 849-863.

Hackett B, Comerma E, Daniel P, Ichikawa H. 2009. Marine oil pollution prediction. Oceanography 22: 168-175.

Hamill TM, Whitaker JS, Snyder C. 2001. Distance-dependent filtering of background error covariance estimates in an ensemble Kalman filter. Mon Weather Rev. 129: 2776-2790.

He Y, Stanev E, Yakushev E, Staneva J. 2012. Black Sea biogeochemistry: Response to decadal atmospheric variability 
during 1960-2000 inferred from numerical modelling. Mar Environ Res. 77: 90-102.

Herzfeld M, Andrewartha J. 2012. A simple, stable and accurate Dirichlet open boundary condition for ocean modelling downscaling. Ocean Model. 43-44: 1-21.

Herzfeld M, Schmidt M, Griffies S, Liang Z. 2011. Realistic test cases for limited area ocean modelling. Ocean Model. 37: $1-34$.

Herzfeld M. 2009. The role of numerical implementation on open boundary behaviour in limited area ocean models. Ocean Model. 27: 18-32, doi:10.1016/j.ocemod.2008.10.008.

Hickey BM. and co-authors.. 2010. River Influences on Shelf Ecosystems: Introduction and synthesis. J Geophys Res. 115: C00B17.

Hodur RM, Pullen J, Cummings J, Hong X, Doyle JD, Martin P, Rennick MA. 2002. The Coupled Ocean/Atmosphere Mesoscale Prediction System (COAMPS). Oceanography 15(1): 88-98.

Hofmann EE, Lascara CM. 1998. Overview of inter-disciplinary modelling for marine ecosystems. Brink $\mathrm{KH}$, Robinson AR The Sea: The Global Coastal Ocean 10: 507-540. Wiley.

Holt J, Butenschon M, Wakelin SL, Artioli Y, Allen JI. 2012. Oceanic controls on the primary production of the northwest European continental shelf: model experiments under recent past conditions and a potential future scenario. Biogeosci. 9: 97-117, doi:10.5194/bg-9-97-2012.

Holt J, Harel J, Proctor R, Michel S, Ashworth M, Batstone C, Allen JI, Holmes R, Smyth TJ, Haines K, Bretherton D, Smith G. 2009. Modelling the global coastal ocean. Philos Trans R Soc A 367: 939-951.

Houtekamer PL, Mitchell HL. 2001. A sequential ensemble Kalman filter for atmospheric data assimilation. Mon Wea Rev. 129: 123-137.

Hu C, Montgomery ET, Schmitt RW, Muller-Karger FE. 2004. The dispersal of the Amazon and Orinoco River water in the tropical Atlantic and Caribbean Sea: Observation from space and S-PALACE floats. Deep-Sea Res II 51: 1151-1171.

Janeiro J, Martins F, Relvas P. 2012. Towards the development of an operational tool for oil spills management in the Algarve coast. J Coast Conserv 16(4): 449-460.

Jordà G, Bolaños R, Espino M, Sánchez-Arcilla A. 2007. Assessment of the importance of the current-wave coupling in the shelf ocean forecasts. Ocean Sci 3: 345-362.

Jouanno J, Sheinbaum J, Barnier B, Molines JM, Debreu L, Lemarie F. 2008. The mesoscale variability in the Caribbean Sea. Part I: Simulations and characteristics with an embedded model. Ocean Model 23: 82-101.

Kelly KA, Beardsley RC, Limeburner R, Brink KH, Paduan JD, Chereskin TK. 1998. Variability of the near-surface eddy kinetic energy in California Current based on altimetric, drifter, and moored current data. J Geophys Res 103: 13067-13083.

Kourafalou VH, Androulidakis YS. 2013. Influence of Mississippi induced circulation on the Deepwater Horizon Oil Spill transport. J Geophys Res 118: 1-20, doi:10.1002/ jgrc. 20272.

Kourafalou VH, Kang H. 2012. Florida Current meandering and evolution of cyclonic eddies along the Florida Keys Reef Tract: are they inter-connected? J Geophys Res 117: C05028, doi:10.1029/2011JC007383.

Kourafalou VH, De Mey P, Le Hénaff M, Charria G, Edwards CA, He R, Herzfeld M, Pasqual A, Stanev E, Tintoré J, Usui N, Van Der Westhuysen A, Wilkin J, Zhu X. 2015. Coastal Ocean Forecasting: system integration and validation. J Oper Oceanogr 7(3): (Special).
Kourafalou VH, Oey L-Y, Lee TN, Wang JD. 1996. The fate of river discharge on the continental shelf. Part II: transport of low-salinity waters under realistic wind and tidal forcing. $\mathrm{J}$ Geophys Res 101(C2): 3435-3455, doi:10.1029/95JC03025.

Kourafalou VH, Peng G, Kang H, Hogan PJ, Smedstad OM, Weisberg RH. 2009. Evaluation of Global Ocean Data Assimilation Experiment products on South Florida nested simulations with the Hybrid Coordinate Ocean Model. Ocean Dyn 59(1): 47-66, doi:10.1007/s10236-008-0160-7.

Kourafalou VH. 2001. Modelling river plumes on Mediterranean shelves: Po River plume (North Adriatic Sea) and Axios River plume (North Aegean Sea). J Mar Syst 30(3-4): 181-205.

Kurapov AL, Foley D, Strub PT, Egbert GD, Allen JS. 2011. Variational assimilation of satellite observations in a coastal ocean model off Oregon. J Geophys Res 116: C05006, doi:10.1029/2010JC006909.

Lazzari P, Teruzzi A, Salon S, Campagna S, Calonaci C, Colella S, Tonani M, Crise A. 2010. Pre-operational short term forecasts for the Mediterranean Sea biogeochemistry. Ocean Sci 6: 25-39.

Le Hénaff M, Kourafalou VH, Paris CB, Helgers J, Hogan PJ, Srinivasan A. 2012. Surface evolution of the Deepwater Horizon oil spill: combined effects of circulation and wind induced drift. Environ Sci Technol 46: 7267-7273, doi:10. 1021/es301570w.

Lentz SJ, Howd MFP, Fredericks J, Hathaway K. 2008. Observations and a model of undertow over the inner continental shelf. J Phys Oceanogr. 38: 2341-2357.

Li Z, Chao Y, McWilliams JC, Ide K. 2008a. A three-dimensional variational data assimilation scheme for the Regional Ocean Modelling System: Implementation and basic experiments. J Geophys Res 113: C05002, doi:10.1029/2006JC004042.

Li Z, Chao Y, McWilliams JC, Ide K. 2008b. A ThreeDimensional Variational Data Assimilation Scheme for the Regional Ocean Modelling System. J Atmos Ocean Technol. 25: 2074-2090.

Lin Y-H, Fang MC, Yeung RW. 2013. The optimization of ship weather-routing algorithm based on the composite influence of multi-dynamic elements. Appl Ocean Res 43: 184-194.

Liu Y, Weisberg RH, Hu C, Zheng L. 2011. Trajectory forecast as a rapid response to the Deepwater Horizon oil spill. In: Monitoring and Modelling the Deepwater Horizon Oil Spill: A Record-Breaking Enterprise, Geophysical Monograph Series 195: 153-165, doi:10.1029/2011GM001121.

Longhurst AR, Sathyendranath S, Platt T, Caverhill CM. 1995. An estimate of global primary production in the ocean from satellite radiometer data. J Plankt Res 17: 1245-1271.

Longuet-Higgins MS. 1970. Longshore currents generated by obliquely incident sea waves: 1. J Geophys Res 75: 6778-6789.

Lucas M, Ayoub N, Barnier B, Penduff T, De Mey P. 2008. Stochastic study of the temperature response of the upper ocean to uncertainties in the atmospheric forcing in an Atlantic OGCM. Ocean Model. 20: 90-113, doi:10.1016/j. ocemod.2007.07.006.

Marchesiello P, McWilliams JC, Shchepetkin A. 2001. Open boundary conditions for long term integration of regional oceanic models. Ocean Model. 3: 1-20.

Mariano AJ, Kourafalou VH, Srinivasan A, Kang H, Halliwell GR, Ryan EH, Roffer M. 2011. On the modelling of the 2010 Gulf of Mexico Oil Spill. Dyn Atmos Oceans 52: 322-340, doi:10.1016/j.dynatmoce.2011.06.001.

Marsaleix P, Auclair F, Floor J, Herrmann M, Estournel C, Pairaud I, Ulses C. 2008. Energy conservation issues in sigma-coordinate free-surface ocean models. Ocean Model 20: 61-89. 
Marta-Almeida M, Hetland RD, Zhang X. 2013a. Evaluation of model nesting performance on the Texas-Louisiana continental shelf. J Geophys Res 118: 2476-2491, doi:10.1002/jgrc. 20163.

Marta-Almeida M, Reboreda R, Rocha C, Dubert J, Nolasco R and co-authors. 2012. Towards Operational Modelling and Forecasting of the Iberian Shelves, Ecosystem. PLoS ONE 7(5): e37343, doi:10.1371/journal.pone.0037343.

Marta-Almeida M, Ruiz-Villarreal M, Pereira J, Otero P, Cirano M, Zhang X, Hetland RD. 2013b. Efficient tools for marine operational forecast and oil spill tracking. Mar Pollut Bull. 71: 139-151.

Martinsen EA, Engedahl H. 1987. Implementation and testing of a lateral boundary scheme as an open boundary condition in a barotropic ocean model. Coast Eng. 11: 603-627.

Mason E, Molemaker J, Shchepetkin AF, Colas F, McWilliams JC, Sangra P. 2010. Procedures for offline grid nesting in regional ocean models. Ocean Model. 35: 1-15, doi:10. 1016/j.ocemod.2010.05.007.

May P, Doyle J, Pullen J, David L. 2011. Two-way coupled atmosphere-ocean modelling of the PhilEx intensive observational period. Oceanography 24(1): 48-57.

McGillicuddy DJ. 2010. Models of harmful algal blooms conceptual, empirical, and numerical approaches preface. J Ma. Syst 83: 105-107, doi:10.1016/j.jmarsys.2010.06.008.

Mellor GL. 2008. The Depth-Dependent Current and Wave Interaction Equations: A Revision. J Phys Oceanogr. 38: 2587-2596, doi:10.1175/2008JPO3971.1.

Mezic I, Loire S, Fonoberov VA, Hogan P. 2010. A new mixing diagnostic and Gulf oil spill movement. Science 330: 486489, doi:10.1126/science. 1194607.

Moll A, Radach G. 2003. Review of three-dimensional ecological modelling related to the North Sea shelf system - part 1: Models and their results. Prog Oceanogr. 57: 175-217, doi:10.1016/S0079-6611(03)00067-3.

Moore AM, Arango HG, Broquet G, Powell BS, Zavala-Garay J, Weaver AT. 2011a. The Regional Ocean Modelling System (ROMS) 4-dimensional variational data assimilation systems. Part I: System overview and formulation. Prog Oceanogr. 91: 34-49.

Moore AM, Arango HG, Broquet G, Edwards C, Veneziani M, Powell B, Foley D, Doyle J, Costa D, Robinson P. 2011b. The Regional Ocean Modelling System (ROMS) 4-dimensional variational data assimilation systems. Part III: Observation impact and observation sensitivity in the California Current System. Prog Oceanogr. 91: 74-94.

Moore AM. 1991. Data Assimilation in a Quasi-geostrophic Open-Ocean Model of the Gulf Stream Region Using the Adjoint Method. J Phys Oceanogr. 21: 398-427.

Murray JM, Codispoti LA, Friederich GE. 1995. Oxidiationreduction encironments: the suboxic zone in the Black Sea. In Aquatic Chemistry: Interfacial and Interspecies Process.

Huang CP, O’ Melia CR, Morgan JJAdv Chem Ser. 224): $157-$ 176.

Murray JW, Jannasch HW, Honjo S, Anderson RF, Reeburgh WS, Top Z, Friederich GE. 1989. Unexpected changes in the oxic/anoxic interface in the Black Sea. Nature 338: 411-13.

Neumann T. 2000. Towards a 3D-ecosystem model of the Baltic Sea. J Mar Syst. 25(3-4): 405-419.

Newberger PA, Allen JS. 2007b. Forcing a three-dimensional, hydrostatic primitive-equation model for application in the surf zone, part 1: Formulation. J Geophy Res. 112: C08018.

Nittis K, Zervakis V, Perivoliotis L, Papadopoulos A, Chronis G. 2001. Operational monitoring and forecasting in the Aegean
Sea: system limitations and forecasting skill evaluation. Marine Pollut Bull. 43: 154-163.

Nobre AM, Ferreira JG, Newton A, Simas T, Icely JD, Neves R. 2005. Management of coastal eutrophication: Integration of field data, ecosystem-scale simulations and screening models. J Mar Syst. 375-390.

Oddo P, Adani M, Pinardi N, Fratianni C, Tonani M, Pettenuzzo D. 2009. A nested Atlantic-Mediterranean Sea general circulation model for operational forecasting. Ocean Sci. 5: 461473.

Oke PR, Allen JS, Miller RN, Egbert GD, Kosro PM. 2002. Assimilation of surface velocity data into a primitive equation coastal ocean model. J Geophys Res. 107(C9): 3122-3147, doi:10.1029/2000JC000511.

Oliger J, Sundstrom A. 1978. Theoretical and practical aspects of some initial boundary value problems in fluid dynamics. SIAM J Appl Math. 35: 419-446.

Panigrahi JK, Padhy CP, Sen D, Swain J, Larsen O. 2012. Optimal ship tracking on a navigation route between two ports: a hydrodynamics approach. J Mar Sci Technol. 17: 59-67.

Paris CB, Le Hénaff M, Aman Z, Suramaniam A, Helgers J, Wang DP, Kourafalou VH, Srinivasan A. 2012. Evolution of the Macondo Well blowout: Simulating the Effects of the Circulation and Synthetic Dispersants on the Subsea Oil Transport. Environ Sci Technol. 46(24): 13293-13302, doi:10.1021/es303197h.

Pauly D, Christensen V. 1995. Primary production required to sustain global fisheries. Nature 374: 255-257.

Pauly D, Christensen V, Guénette S, Pitcher TJ, Sumaila UR, Walters CJ, Watson R, Zeller D. 2002. Towards sustainability in world fisheries. Nature 418: 689-695.

Proctor R, Holt JT, Allen JI, Blackford J. 2003. Nutrient fluxes and budgets for the North West European Shelf from a three-dimensional model. Sci Total Environ. 314: 769-785, doi:10.1016/S0048-9697(03)00083-4.

Pullen J, Bruno M. 2014. The Center for Secure and Resilient Maritime Commerce: A DHS National Center of Excellence in Maritime Security. In Cases on Research and Knowledge Discovery: Homeland Security Centers of Excellence, doi:10.4018/978-1-4666-5946-9.ch002.

Pullen J, Doyle J, May P, Chavanne C, Flament P, Arnone R. 2008. Monsoon surges trigger oceanic eddy formation and propagation in the lee of the Philippine Islands. Geophys Res Lett. 35: L07604, doi:10.1029/2007GL033109.

Pullen J, Gordon AL, Sprintall J, Lee CM, Alford MA, Doyle JD, May PW. 2011. Atmospheric and oceanic processes in the vicinity of an island strait. Oceanography 24(1): 112121.

Ramp SR, Davis RE, Leonard NE, Shulman I, Chao Y, Robinson AR, Marsden J, Lermusiaux P, Frantantoni D, Paduan JD, et al. 2009. Preparing to predict: The Second Autonomous Ocean Sampling Network (AOSN-II) experiment in the Monterey Bay. Deep Sea Res II 56: 68-86.

Rascle N, Ardhuin F. 2009. Drift and mixing under the ocean surface revisited: stratified conditions and model-data comparisons. J Geophys Res. 114: C02016, doi:10.1029/ 2007JC004466.

Russo A, Coluccelli A, Iermano I, Falcieri F, Ravaioli M, Bortoluzzi G, Focaccia P, Stanghellini G, Ferrari CR, Chiggiato J, Deserti M. 2009. An operational system for forecasting hypoxic events in the Northern Adriatic Sea. Geofizika 26: 191-213.

Rypina I, Pratt L, Pullen J, Levin J, Gordon A. 2010. Chaotic advection in an archipelago. J Phys Oceanogr. 40(9): 19882006. 
Sachsperger J. 2012. Study of the Atmospheric Wake of Madeira Island. Ph.D. Dissertation, University of Vienna.

Sarmiento JL, Slater R, Barber R, and co-authors. 2004. Response of ocean ecosystems to climate warming. Glob Biogeochem Cycles 18: GB3003, doi:10.1029/2003GB 002134.

Schiller A, Herzfeld M, Brinkman R, Stuart G. 2014. Monitoring, Predicting and Managing one of the Seven Natural Wonders of the World. Bull Am Meteorol Soc. 95(1): 23-30, http:// dx.doi.org/10.1175/BAMS-D-12-00202.1.

Shchepetkin AF, McWilliams JC. 2005. The Regional Oceanic Modelling System: A split-explicit, free-surface, topographyfollowing-coordinate ocean model. Ocean Model. 9: 347-404.

Siddorn JR, Allen JI, Blackford JC, Gilbert FJ, Holt JT, Holt MW, Osborne JP, Proctor R, Mills DK. 2007. Modelling the hydrodynamics and ecosystem of the North-west European Continental Shelf for operational oceanogra-phy. J Mar Syst 65: 417-429, doi:10.1016/j.jmarsys.2006.01.018.

Smith SV, Hollibaugh JT. 1993. Role of coastal ocean organic metabolism in the oceanic organic carbon balance. Rev Geophys. 31: 75-89.

Soares ID, Kourafalou VH, Lee TN. 2007. The Western South Atlantic Continental Shelf circulation. Part 2: Spring and Autumn realistic simulations. J Geophys Res. 112: C04003, doi:10.1029/2006JC003620.

Sponaugle S, Lee TN, Kourafalou VH, Pinkard D. 2005. Florida Current frontal eddies and the settlement of coral reef fishes. Limnol Oceanogr. 50: 1033-1048.

Sponaugle S, Paris C, Walter K, Kourafalou VH, D’ Alessandro E. 2012. Observed and modeled larval settlement of a reef fish to the Florida Keys. Mar Ecol Prog Ser. 453: 201-212, doi:10. 3354/meps09641.

Stanev EV, He Y, Grayek S, Boetius A. 2013. Oxygen dynamics in the Black Sea as seen by Argo profiling floats. Geophys Res Lett. 40: 3085-3090.

Stanev E, Schulz-Stellenfleth J, Staneva J, Grayek S, Seemann J, Petersen W. 2011. Coastal observing and forecasting system for the German Bight. Estimates of hydro-physical states. Ocean Sci. 7: 1-15.

Stanev EV, Bowman MJ, Peneva EL, Staneva JV. 2003b. Control of Black Sea intermediate water mass formation by dynamics and topography: comparison of numerical simulations, surveys and satellite data. J Mar Res. 61: 59-99.

Stanev EV, Wolf JO, Burchard H, Bolding K, Floser G. 2003a. On the circulation in the East Frisian Wadden Sea: numerical modelling and data analysis. Ocean Dyn. 53: 27-51, doi:10. 1007/s10236-002-0022-7.

Svendsen IA, Putrevu U. 1994. Nearshore mixing and dispersion. Proc: Math Phys Sci, Royal Society London A 445: 561-576.

Talagrand O, Courtier P. 1987. Variational Assimilation of Meteorological Observations With the Adjoint Vorticity Equation. I: Theory. Q J R Meteorol Soc. 113(478): 13111328, doi:10.1002/qj.49711347812.

Tandeo P, Autret E, Chapron B, Fablet R, Garello R. 2014. SST spatial anisotropic covariances from METOP-AVHRR data. Remote Sens Environ. 141: 144-148, doi:10.1016/j.rse. 2013.10.024.

Treguier A, Barnier M, De Miranda AP, Molines JM, Grima N, Imbard M, Madec G, Messager C. 2001. An eddy permitting model of the Atlantic circulation: evaluating open boundary conditions. J Geophys Res. 106(C10): 22115-22130.

Tsagareli KN, Babanin AV, Walker DJ, Young IR. 2010. Numerical investigation of spectral evolution of wind waves. Part I: Wind-input source function. J Phys Oceanogr. 40: 656-666.

Tsiaras KP, Kourafalou VH, Davidov A, Staneva J. 2008. A threedimensional coupled model of the western Black Sea plankton dynamics: Seasonal variability and comparison to SeaWiFS data. J Geophys Res. 113, doi:10.1029/2006JC003959.

Veneziani M, Edwards CA, Doyle JD, Foley D. 2009. A central California coastal ocean modelling study: 1 . Forward model and the influence of realistic versus climatological forcing. J Geophys Res. 114: C04015, doi:10.1029/2008JC004774.

Wang X, Chao Y, Dong C, Farrara J, Li Z, McWilliams JC, Paduan JD, Rosenfeld LK. 2009. Modelling tides in Monterey Bay, California. Deep-Sea Res Part 2 56: 219-231.

Weisberg RH, Zheng L, Liu Y. 2011. Tracking subsurface oil in the aftermath of the Deepwater Horizon well blowout. In: Monitoring and Modelling the Deepwater Horizon Oil Spill: A Record-Breaking Enterprise, Geophys Monogr Ser. 195: 205-215, doi:10.1029/2011GM001131.

Weisberg RH, Zheng L, Liu Y, Lembke C, Lenes JM, Walsh JJ. 2014a. Why no red tide was observed on the West Florida Continental Shelf in 2010. Harmful Algae, doi:10.1016/j. hal.2014.04.010.

Weisberg RH, Zheng L, Peebles E. 2014b. Gag grouper larvae pathways on the West Florida Shelf. Cont Shelf Res. 88: $11-23$.

Weisberg RH, Zheng L, Liu Y, Murawski S, Hu C, Paul J. 2014c. Did Deepwater Horizon Hydrocarbons Transit to the West Florida Continental Shelf? Deep-Sea Res Part II, doi:10. 1016/j.dsr2.2014.02.002.

Wild-Allen K, Herzfeld M, Thompson PA, Rosebrock U, Parslow J, Volkman JK. 2010. Applied coastal biogeochemical modelling to quantify the environmental impact of fish farm nutrients and inform managers. J Mar Syst. 81: 134-147, doi:10. 1016/j.jmarsys.2009.12.013.

Yakushev EV, Pollehne F, Jost G, Kuznetsov I, Schneider B, Urnlauf L. 2007. Analysis of the water column oxic/anoxic interface in the Black and Baltic seas with a numerical model. Mar Chem. 107: 388-410.

Zamudio L, Metzger EJ, Hogan P. 2011. Modelling the seasonal and interannual variability of the northern Gulf of California salinity. J Geophys Res. 116: C02017, doi:10. 1029/2010JC006631.

Zhang Y, Baptista AM. 2008. SELFE: a semi-implicit EulerianLagrangian finite-element model for cross-scale ocean circulation. Ocean Model. 21(3): 71-96.

Zheng L, Weisberg RH. 2012. Modelling the West Florida Coastal Ocean by Downscaling from the Deep Ocean, Across the Continental Shelf and into the Estuaries. Ocean Model. 48: 10-29, doi:10.1016/j.ocemod.2012.02.002.

Zhu J, Weisberg RH, Zheng L, Han S. 2014a. Influences of channel deepening and widening on the tidal and non-tidal circulation of Tampa Bay. Estuar Coast doi:10.1007/ s12237-014-9815-4.

Zhu J, Weisberg RH, Zheng L, Han S. 2014b. On the flushing of Tampa Bay. Estuar Coast. doi:10.1007/s12237-014-9793-6. 